\title{
Beheersbaarheid van het onbeheersbare
}

Citation for published version (APA):

Hosman, C. M. H. (1996). Beheersbaarheid van het onbeheersbare: over management van effectieve preventie. Maastricht University. https://doi.org/10.26481/spe.19960607ch

Document status and date:

Published: 07/06/1996

DOI:

10.26481/spe.19960607ch

Document Version:

Publisher's PDF, also known as Version of record

\section{Please check the document version of this publication:}

- A submitted manuscript is the version of the article upon submission and before peer-review. There can be important differences between the submitted version and the official published version of record.

People interested in the research are advised to contact the author for the final version of the publication, or visit the DOI to the publisher's website.

- The final author version and the galley proof are versions of the publication after peer review.

- The final published version features the final layout of the paper including the volume, issue and page numbers.

Link to publication

\footnotetext{
General rights rights.

- You may freely distribute the URL identifying the publication in the public portal. please follow below link for the End User Agreement:

www.umlib.nl/taverne-license

Take down policy

If you believe that this document breaches copyright please contact us at:

repository@maastrichtuniversity.nl

providing details and we will investigate your claim.
}

Copyright and moral rights for the publications made accessible in the public portal are retained by the authors and/or other copyright owners and it is a condition of accessing publications that users recognise and abide by the legal requirements associated with these

- Users may download and print one copy of any publication from the public portal for the purpose of private study or research.

- You may not further distribute the material or use it for any profit-making activity or commercial gain

If the publication is distributed under the terms of Article $25 \mathrm{fa}$ of the Dutch Copyright Act, indicated by the "Taverne" license above, 
Unlversiteitsblbliotheek

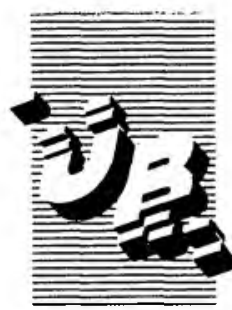

De uitleentermijn verstrijkt op:

23 MARRT 1999

-5 OKT. 1999

-2 OKT. 2000

Universiteit Maastricht

Postbus 616

6200 MD Maastricht

Gelieve deze publicatie tijdig te retourneren of (telefonisch) verlenging van de uitleentermijn aan te vragen.

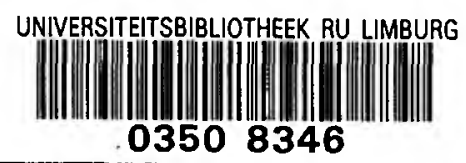


Beheersbaarheid van het onbeheersbare 


\section{Beheersbaarheid van het onbeheersbare over management van effectieve preventie}

Rede

in verkorte vorm uitgesproken bij de aanvaarding van het ambt van bijzonder hoogleraar in de preventieve geestelijke gezondheidszorg aan de Faculteit der Gezondheidswetenschappen van de Rijksuniversiteit Limburg op vrijdag 7 juni 1996

door

dr. Clemens M.H. Hosman 
De leerstoel Preventieve Geestelijke Gezondheidszorg is ingesteld vanwege de Nederlandse Vereniging voor Preventie en Gezondheidsvoorlichting (NVPG) met steun van het Nationaal Fonds Geestelijke Volksgezondheid

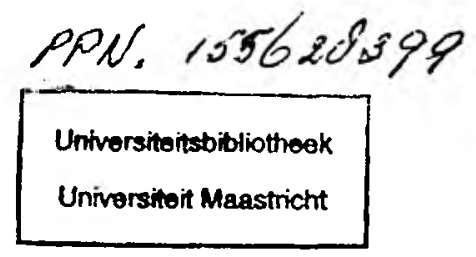

- 1996 C.M.H. Hosman

ISBN 9090103309

NUGI $735 / 744 / 712$

Trefw: preventie, geestelijke volksgezondheid

Besteladres exemplaren:

Vakgroep Gezondheidsvoorlichting, Universiteit Maastricht

Postbus 616 6200 MD Maastricht 
Meneer de Rector Magnificus, Zeer gewaardeerde toehoorders

\section{Een idee met een geschiedenis}

Ruim negentig jaar geleden schreef een Amerikaanse psychiatrische patiënt in zijn dagboek de volgende zinsnede: "Zou het niet mogelijk zijn ten minste sommige oorzaken (ch: van geestesziekte) te ontdekken en deze uit te bannen. Vele levens zouden daardoor kunnen worden gered en in geld vele miljoenen bespaard. Ooit zal er een dag aanbreken dat er iets wordt uitgevonden om een volledige en ongeneeslijke psychische ineenstorting te voorkómen." I De datum: 1 januari 1905. De patiënt leed aan een ernstige manisch-depressieve stoornis. Zijn naam: Clifford Beers, een verzekeringsagent en afgestudeerd aan de Yale University. Na een mislukte suicide-poging door uit het raam van de vierde verdieping van zijn ouderlijk huis te springen, verbleef hij enkele jaren in diverse sanatoria en psychiatrische inrichtingen. $\mathrm{Na}$ zijn herstel en terugkeer in de samenleving schreef hij een indrukwekkend boek over het verloop van zijn ziekte en vooral over de afschuwelijke wantoestanden die hij als patiënt in verschillende inrichtingen had meegemaakt. Dit boek 'A mind that found itself', voor het eerst gepubliceerd in 1908, werd een internationale bestseller, met 34 herdrukken over een periode van bijna 50 jaar. In de epiloog die hij in een van de latere edities toevoegde beschrijft hij het boek als "het startschot voor een permanente campagne voor de verbetering van de zorg aan en behandeling van degenen die ernstig psychisch lijden en, voorzover mogelijk, voor de preventie van geestesziekte" (Beers, 1929, p. 255). Op 19 februari 1909 werd daartoe in Hotel Manhattan te New York een 'National Committee for Mental Hygiene' opgericht. De doelstellingen waren tweeledig, enerzijds de bescherming van de geestelijke gezondheid en de preventie van geestesziekte en anderzijds de verbetering van het lot en de behandeling van psychiatrische patiënten.

Interessant is te vermelden dat zich onder dit comité van oprichters twee namen bevonden van mensen die in de wetenschap ook vandaag nog grote bekendheid genieten. De ene was William James, een van de eerste grote Amerikaanse psychologen. De tweede was de psychiater Adolf Meyer, 
een van de grondleggers van de Amerikaanse psychiatrie. Het was met name Adolf Meyer die er zich met Beers voor heeft ingespannen de 'preventie van geestesziekte' te maken tot een van de belangrijke doelen van deze 'Mental Hygiene Movement'2. Zijn voorwaarde voor deelname was dat de ontwikkeling van preventie zou worden gebaseerd op een degelijke wetenschappelijke fundament.

Rond de eeuwwisseling bestond een zeker optimisme over de mogelijkheden om de geestelijke gezondheid van de bevolking te verbeteren en geestesziekten te voorkómen. Dit werd gevoed door de hoge verwachtingen over de kennis die de nog jonge wetenschappen als de psychiatrie, sociologie, psychologie en de pedagogische wetenschappen zouden opleveren over de oorzaken van geestesziekte. Bovendien waren in de $19 \mathrm{e}$ eeuw al grote successen geboekt op het terrein van de sociale geneeskunde door hygiënische maatregelen als controle op de drinkwatervoorziening, de aanleg van riolen, en de ontwikkeling van zwangerschapsbegeleiding en zuigelingenzorg. Dit deed de hoop groeien dat dergelijke maatregelen ook mogelijk zouden zijn op het terrein van de geestelijke gezondheid, vandaar de term psychohygiëne. Er bestonden in die tijd dus grote verwachtingen ten aanzien van de beheersbaarheid van de volksgezondheid, inclusief de geestelijke volksgezondheid.

De idee dat geestesziekte kon worden voorkómen, was op zich geen unieke vondst van Clifford Beers en zijn medestanders. Zowel in Europa als in de Verenigde Staten hebben in die tijd meerdere deskundigen gepleit voor preventie en bevordering van de geestelijke gezondheid. Eén van hen was de sociaal-geneeskundige Alfred Adler, die samen met Freud en Jung de kern vormde van het Weense Psychoanalytische genootschap. Volgens Adler had de huisarts een belangrijke taak in het bevorderen van de geestelijke gezondheid. In 1904, schreef hij, 'Niet de behandeling en de genezing van zieke kinderen, maar de bescherming van gezonde kinderen tegen ziekte is het meest logische en uiteindelijk het hoogste doel van de medische wetenschap' (Adler, 1904, p. 203). Artsen hebben een taak in het bevorderen van zelfvertrouwen bij kinderen en in het ontwikkelen van hun vaardigheden om met levensproblemen om te gaan.

In zijn theorie over de psychobiologie beschreef Adolf Meyer in het begin van deze eeuw psychische stoornissen als pathologische vormen van 
aanpassing aan de eisen, beperkingen en bedreigingen van de omgeving ${ }^{3}$. Pathologie is het resultaat van een foutgelopen wisselwerking tussen biologische, psychologische en sociale krachten, en ieder van deze krachten kan op preventieve wijze worden beïnvloed, aldus Meyer. De psychohygiënische beweging streefde ernaar om in scholen, bedrijven, de vrijetijdssector en in het woonklimaat de omstandigheden die een bedreiging vormen voor de geestelijke gezondheid op te heffen en de krachten die de geestelijke gezondheid bevorderen te versterken. Het concept voor het huidige facet-beleid uit de Nota $2000^{4}$ was kennelijk al rond 1900 geschreven. Een belangrijke focus vormde met name de jeugd en opvoedingsprocessen. Voorlichting aan opvoeders en vroegtijdige hulpverlening zouden latere psychopathologie en zelfs delinquentie kunnen voorkomen.

Gesteund door een invloedrijke groep van wetenschappers en zakenlieden groeide het initiatief van Beers binnen enkele jaren uit tot een internationale beweging. In 1930 bij het eerste Wereldcongres van de beweging waren er vertegenwoordigers uit vijftig landen, waaronder veel Europese landen, inclusief Nederland. Terugkijkend vanuit de hedendaagse preventiesituatie zouden we Clifford Beers met recht als de eerste preventiewerker en zijn comité als het eerste preventieteam kunnen beschouwen.

Direct na de Tweede Wereldoorlog werd de naam 'Mental hygiene' vervangen door de term 'Mental health's Sinds de Tweede Wereldoorlog is het de World Federation for Mental Health die zich internationaal sterk maakt voor het verder realiseren van de oorspronkelijke doelen van de psychohygiënische beweging. Al bijna vijftig jaar is deze Federatie een sterk pleitbezorger voor de verbetering van het lot van psychiatrische patiënten, de ontwikkeling van preventie en de bevordering van geestelijke gezondheid'.

Ook in Nederland heeft de psychohygiënische beweging vanaf de twintiger jaren duidelijk weerklank gevonden. Grote pleitbezorgers waren de psychiaters Bouman?, Querido en Trimbos en de psychologen Buytendijk en Fortman. Vandaag de dag en al sinds 1949 is in ons land het Nationaal Fonds voor de Geestelijke Volksgezondheid de belangrijkste en meest rechtstreekse vertegenwoordiger van de oorspronkelijke psychohygiënische beweging, later geheten de beweging voor geestelijke volksgezondheid. De steun die dit fonds recentelijk gegeven heeft bij de totstandkoming van leerstoelen onder meer op het terrein van de ambulante gees- 
telijke gezondheidszorg, de preventie en het onderzoek, weerspiegelt op een heldere wijze de belangrijkste doelstellingen die bijna 90 jaar geleden door Adolf Meyer als kernthema's van de psychohygiënische beweging werden bepleit.

\section{Betekenis van de psychohygiëne}

Welke resultaten hebben deze bewegingen opgeleverd op het terrein van de preventie? Hun belangrijkste successen liggen vooral op het terrein van de sociale psychiatrie. De wantoestanden in psychiatrische inrichtingen zijn verdwenen, de kwaliteit van de behandelingen is aanzienlijk verbeterd, chronische psychiatrische patiënten worden op velerlei wijze begeleid zodat ze zich beter in de samenleving buiten de inrichting kunnen handhaven, patiënten hebben zich georganiseerd en invloed verworven, en door voorlichting over de psychiatrie en psychiatrische patiënten is het taboe op geestesziekte sterk verminderd. Psychiatrische patiënten, hun problematiek en handicaps, hun leefsituatie en behandelmogelijkheden zijn een regelmatig thema in de media.

In de klassieke terminologie van preventie, zouden we dit successen kunnen noemen op het terrein van de tertiaire preventie. Kort gezegd: voorkómen dat psychische stoornissen en handicaps uitmonden in een schier eindeloze keten van nieuwe problemen en aantastingen van een menswaardig bestaan ${ }^{8}$.

Hoe zit het met de successen op de beide andere terreinen van de preventie, de primaire en secundaire preventie. Voor wat deze typen preventie betreft is de geschiedenis van de psychohygiëne bepaald geen onverdeelde 'success-story'.

Het belangrijkste wapenfeit is ongetwijfeld de ontwikkeling van een reeks bureaus voor ambulante hulpverlening ${ }^{9}$ in de eerste helft van deze eeuw, zoals de Medisch Opvoedkundige Bureaus, Sociaal-Psychiatrische Diensten en Bureaus voor Levens- en Gezinsvragen. Een essentieel kenmerk van deze bureaus was hun preventieve oriëntatie: het voorkómen van opnamen en heropnamen via vroegtijdige hulp en nazorg, en vroege hulp aan kinderen die in problemen dreigen te raken om latere stoornissen en delinquentie te voorkomen; ook opvoedingsvoorlichting aan ouders en leerkrachten behoorden tot hun taken. Uit deze bureaus zijn de huidige 
RIAGG's ontstaan.

Daarnaast werd door de psychohygiënisten veel aandacht besteed aan voorlichting over geestelijke gezondheid aan het grote publiek en aan maatschappelijke sleutelfiguren ${ }^{10}$. Sommigen van $u$ herinneren zich wellicht nog de rode oortjes waarmee in de jaren vijftig naar de radiouitzendingen van Trimbos over seksualiteit geluisterd werd.

De beweging voor de geestelijke volksgezondheid bleek echter niet in staat voor de preventie en geestelijke gezondheidsbevordering een degelijk wetenschappelijk fundament te ontwikkelen, de relevante wetenschappen waren daarvoor simpelweg nog lang niet ver genoeg ontwikkeld." Om deze reden bleef de beweging steeds gekenmerkt door een sterk moralistische benadering.

\section{Ontwikkeling van ggz-preventie na 1970}

Dankzij de vele pleidooien van onder meer Trimbos en dankzij de opnieuw optimistische cultuur van de jaren zeventig, kwam er rond 1970 toch een vrij unieke impuls tot stand voor de ontwikkeling van preventieve geestelijke gezondheidszorg, kortweg 'ggz-preventie'. Vanaf die datum doen de gespecialiseerde preventiewerker en gezondheidsvoorlichter hun intrede in de geestelijke gezondheidszorg. De overheid bleek bereid om stap voor stap de ontwikkeling van een regionale en landelijke infrastructuur voor preventie te financieren. Hun intrede in de (geestelijke) gezondheidszorg vond echter plaats met een grotendeels lege rugzak, géén wetenschappelijk fundament, géén specifieke opleiding en géén preventiebeleid. De eerste generatie van preventiewerkers en gvo-functionarissen kan dan ook eerder gekenschetst worden als 'uitvinders' dan als gespecialiseerde preventiedeskundigen.

De sterk op het welzijn gerichte ideologie van de jaren zeventig en de groeiende kritiek op de psychiatrie, de anti-psychiatrie, hebben een sterk stempel gedrukt op de geboorte en de kinderjaren van deze preventiesector. Op de denkcultuur van die tijd sloten de psychohygiënische gedachten over het bevorderen van geestelijke gezondheid naadloos aan: ontplooiing, emancipatie, jezelf ontdekken, sociale vaardigheden en zelfvertrouwen ontwikkelen, en het creëren van meer kansen voor onderdrukte groepen, waren de favourite thema's van die tijd ${ }^{12}$. Werken aan preventie van psychische stoornissen, was ofwel niet in de picture of werd 
gezien als een knieval voor de toen verguisde psychiatrie en het medisch model. Juist omdat de preventiesector in die tijd ontstaan is, en dus in haar inprentingsfase was, heeft deze oriëntatie nog lang de preventiewereld gedomineerd. Dat was nog steeds het geval toen in de tachtiger jaren de rest van de geestelijke gezondheidszorg haar koers al verlegd had naar de psychiatrie. Vanuit de psychiatrie bezien diende de preventie zich vooral bezig te houden met de weer opnieuw in de aandacht staande chronisch psychiatrische patiënt en met het verbeteren van zijn kansen in de samenleving. De welzijnsideologie van de preventiewerkers was hun een doorn in het oog, of liever gezegd een gruwel. Pas vanaf de tweede helft van de tachtiger jaren richt de ggz-preventie zich ook actief op de psychiatrie, met name rond opnamepreventie, suïcidepreventie en kinderen van ouders met psychiatrische problemen

Deze historie bepaalt tot op de dag van vandaag bij vele buitenstaanders nog steeds de beeldvorming over de ggz-preventie, de associatie met een geiten-haren-wollen-sokken club, hoewel die associatie geenszins past bij de huidige preventiewerker. Deze beeldvorming is de sector duur komen te staan en heeft ongetwijfeld bijgedragen aan haar nog steeds marginale positie. De tegenstelling tussen de welzijns- en de psychiatrie-oriëntatie, tussen geestelijke gezondheidsbevordering en preventie is tot op heden nooit echt opgelost. Een functionele integratie van beide benaderingen is op wetenschappelijke gronden naar mijn oordeel echter zeer wel voorstelbaar en zelfs zeer gewenst.

Sinds de jaren zeventig zijn in vrijwel alle RIAGG's en Centra voor Verslavingszorg aparte preventieteams opgezet, binnen Europa een volstrekt unicum. Met het invoeren van de Wet op de Collectieve Preventie in 1990 hebben bovendien de gezondheidsvoorlichters en epidemiologen van de GGD-en een taak gekregen op het terrein van de psychohygiëne. Aan deze lijst kunnen we ook de preventiewerkers van Stichtingen voor Spel en Opvoeding toevoegen. Hun werk op het terrein van de opvoedingsvoorlichting representeert bij uitstek het oorspronkelijke gedachtengoed van de psychohygiëne. Bij elkaar opgeteld gaat het om ongeveer 600 gespecialiseerde beroepskrachten ${ }^{13}$ die zich in Nederland full-time of parttime inzetten voor het bevorderen van geestelijke gezondheid en het voorkómen van psychische stoornissen. Tezamen hebben zij de afgelopen vijfentwintig jaar enkele duizenden preventieprojecten uitgevoerd. Ook 
vele andere beroepen en organisaties voeren impliciet of expliciet taken uit op het gebied van de ggz-preventie. Voorbeelden hiervan zijn huisartsen, werkers in de thuiszorg, schooldekanen en leerlingbegeleiders, psychotherapeuten, medisch-psychologen in algemene ziekenhuizen, bureau's slachtofferhulp, de Vereniging tegen Kindermishandleing en verenigingen van chronische patiënten. Het gebied breidt zich steeds verder uit zoals bijvoorbeeld blijkt uit het ontstaan van tal van bureaus voor training in stressmanagement en de recente ontwikkeling van ARBO-diensten ten behoeve van preventie in bedrijven.

Op landelijk niveau is een ondersteunende infrastructuur ontwikkeld. De belangrijkste rollen worden daarbij vervuld door de Nederlandse Vereniging voor Ambulante Geestelijke Gezondheidszorg als pionier op dit terrein, het Landelijk Ondersteuningspunt Preventie als landelijke communicator en stimulator, het Landelijk Centrum GVO, thans Nederlands Instituut voor Gezondheidsbevordering en Preventie als kwaliteitsbevorderaar, het Nederlands centrum Geestelijke volksgezondheid als praktijkondersteunend onderzoeksinstituut, en de Nederlandse Beroepsvereniging voor Preventie en GVO als formele vertegenwoordiger en belangenbehartiger.

De samenleving is de laatste decennia steeds meer een preventief georienteerde samenleving geworden. Toen $\mathrm{ik}$ mij rond 1970 voor het eerst ging bezig houden met preventie, werd het woord nog uiterst weinig gebruikt. Het haalde de pers alleen in relatie tot het voorkómen van besmettelijke ziekten. Vandaag de dag, slechts vijfentwintig jaar later is iedereen in de samenleving met dit begrip vergroeid. Het is dagelijks in de krant en op radio en TV te vinden, in advertenties en huis-aan-huis folders: inbraakpreventie, brandpreventie, ongevallenpreventie, schadepreventie, fraudepreventie, milieupreventie, aidspreventie, preventie van sportblessures en ga zo maar door.

\section{Kritieken en scepsis: onbeheersbaarheid}

Hoewel er ook waardering bestaat voor de vele preventieprojecten en innovaties binnen de GGZ die door preventiewerkers zijn uitgevoerd, bestaat er onmiskenbaar ook veel twijfel aan de zin van het preventiewerk en kritiek op de wijze waarop het preventiewerk wordt ingevuld. Die 
kritiek komt zowel van binnen als van buiten de geestelijke gezondheidszorg en is al decennia lang een regelmatig terugkerend agendapunt. In de kern gaat het hierbij steeds om drie soorten van twijfels en kritieken die alle beheersbaarheid en onbeheersbaarheid als gemeenschappelijk thema hebben:

- twijfel aan de noodzaak van beheersen van geestelijke volksgezondheid

- twijfel aan de mogelijkheid van haar beheersing via preventie

- twijfel aan de beheersbaarheid van de preventiesector zelf.

Alle kritiek samengevoegd komt het er op neer dat er getwijfeld wordt aan de zin van ggz-preventie omdat zij als een onbeheersbare sector de illusie heeft de geestelijke volksgezondheid te kunnen beheersen die per definitie of minstens voorlopig onbeheersbaar is. En wie wil daar nu investeren? De meningen over de zin en onzin van preventie zijn verdeeld. De ggz-preventie weet zich dan ook niet verzekerd van een vanzelfsprekende maatschappelijke en politieke steun, zoals die in onze samenleving bijvoorbeeld wel het aanwezig is als het gaat om de preventie van kanker, hart- en vaatziekten, verkeersongevallen en AIDS. Het lijkt me daarom belangrijk de verschillende twijfels en kritieken aan een kritisch onderzoek te onderwerpen.

\section{Twijfel aan de noodzaak van het beheersen van geestelijke volksge- zondheid}

Hoe belangrijk is het om als samenleving te investeren in preventie op het gebied van de geestelijke volksgezondheid? De twijfel aan de noodzaak betreft hier niet zozeer de zinvolheid van preventie 'an sich' maar vooral het antwoord op de vraag hoeveel prioriteit wij als samenleving aan de preventie van psychische stoornissen en de bevordering van geestelijke gezondheid willen geven. Om u hierover een oordeel te kunnen vormen geef ik $u$ enkele cijfers en overwegingen.

Nederlands en buitenlands onderzoek leidt tot de conclusie dat de jaarprevalentie, dus het percentage mensen met een psychiatrische stoornis, geschat kan worden op ongeveer $15 \%^{14}$. Dat betekent dat in één jaar tenminste 2.2 miljoen Nederlanders een periode van psychiatrische problematiek doormaakt, vaak gepaard gaande met veel psychisch lijden voor de betrokkenen en hun omgeving, of met een ernstige verstoring van hun dagelijks functioneren. 
Diverse deskundigen gaan ervan uit dat er op meerdere fronten rekening gehouden moet worden met een verdere toename van het aantal psychiatrische ziekten in de samenleving. ${ }^{15}$ In ieder geval is het aantal mensen dat een beroep doet op voorzieningen voor geestelijke gezondheidszorg sinds 1980 drastisch gestegen. Voor de RIAGG's bedroeg die stijging in 10 jaar $112 \% .{ }^{16}$ In 1993 ontvingen ongeveer 600.000 mensen enigerlei vorm van psychiatrische of psychotherapeutische hulp. Desondanks blijkt deze hulpvraag nog maar een beperkt deel te vormen van de totale groep mensen in de samenleving die aan psychische stoornissen leidt. ${ }^{17}$

Ook in economische zin zijn de gevolgen voor de samenleving groot. De directe kosten van de geestelijke gezondheidszorg bedragen inmiddels jaarlijks 5 miljard. ${ }^{18}$ Deze kosten stijgen veel sneller dan de inflatie en dat leidt tot een hogere premiedruk. In termen van produktiviteitsverlies voor het bedrijfsleven blijkt depressie tot een groter verlies aan arbeidsdagen te leiden dan welke andere ziekte dan ook met uitzondering van hart- en vaatziekten ${ }^{19}$. Bovendien is een derde van het aantal arbeidsongeschikten niet in staat tot werken vanwege een psychische stoornis, een kostenpost van nog eens 6,5 miljard.

Kortom, er blijkt sprake te zijn van een volksziekte met grote sociale en economische gevolgen. Het lijkt me daarom hoog tijd serieus na te denken over een Nationaal Ontwikkelingsplan voor preventie op het terrein van de geestelijke volksgezondheid.

\section{Twijfel aan de beheersbaarheid van psychische stoornissen en zorgconsumptie}

De meest intrigerende vraag waar het in de ggz-preventie thans omgaat is uiteraard: Is de geestelijke volksgezondheid en de hulpvraag via preventie beheersbaar? Is ggz-preventie een handel in illusies of een handel in effecten?

Over de mogelijkheden van effectieve preventie bestaan zowel binnen als buiten de GGZ ernstige twijfels. De psychohygiënisten aan het begin van deze eeuw waren hierover nogal optimistisch. "Onder de jeugd van dit land kan tenminste de helft van het grote aantal gevallen van psychische stoornissen worden voorkómen wanneer we met name in de kindertijd de informatie en de praktische ondersteuningsmogelijkheden toepassen die ons thans ter beschikking staan", aldus een uitspraak van een bekende 
psychiater uit die tijd ${ }^{20}$.

In de hedendaagse oordeelsvorming over de zin van ggz-preventie heeft een publikatie van de Groningse epidemioloog Ormel in 1987 een grote rol gespeeld (Ormel, 1987). In dit artikel in het Maandblad Geestelijke Volksgezondheid neemt hij een zeer negatief standpunt in over de mogelijkheid om veelvoorkomende psychische stoornissen via primaire preventie te verminderen. In zijn opvatting zal het niet of nauwelijks mogelijk zijn belangrijke stressoren in het leven van mensen te verminderen, althans zeker niet vanuit de geestelijke gezondheidszorg. Mogelijk kunnen programma's ontwikkeld worden om de psychosociale weerbaarheid van mensen te vergroten, maar het zal niet lukken die op grote schaal, bijvoorbeeld in het onderwijs ingevoerd te krijgen.

Ook de socioloog Schnabel is niet erg optimistisch. In 'De toekomst heeft tijd nodig' stelt hij dat er althans vóór het jaar 2000 geen wetenschappelijke doorbraken te verwachten zijn in de preventie van ernstige psychische stoornissen of in het verlagen van de behoefte aan hulp door middel van preventie (Schnabel, 1988). In zijn recente en intrigerende boek 'De weerbarstige geestesziekte' schetst Schnabel zijn verwachtingen omtrent de geestelijke gezondheidszorg aan het einde van de 21 ste eeuw (Schnabel, 1995). Tegen die tijd zullen de mogelijkheden om de psychiatrische morbiditeit te beïnvloeden hoofdzakelijk het gevolg zijn van de te verwachten vorderingen op het terrein van de biologische psychiatrie. Hij denkt daarbij vooral aan biologische interventies via zeer geavanceerde psychofarmaca en electronica. Over de effectiviteit van gedragsgerichte en sociale interventies zijn zijn verwachtingen kennelijk niet hoog gespannen, ze komen in deze toekomstschets eenvoudigweg niet voor. Ook de ziektekostenverzekeraars blijken geen hoge verwachtingen te hebben van het rendement van ggz-preventie, zeker niet als het gaat om kostenbesparende effecten. Als de ziektekostenverzekeraar moet kiezen tussen investeren in preventie of meer en beter behandelen, zal hij kiezen voor het laatste (Holman, 1992).

Hoe denken de hedendaagse preventiedeskundigen hier zelf over? Sinds de zeventiger jaren zijn de preventiedeskundigen en gezondheidsvoorlichters realistischer geworden. Het gaat niet meer om het idee van de maakbaarheid van de samenleving, maar de beïnvloedbaarheid van de samenleving. Preventiedeskundigen anno 1996 verschillen daarin weinig van 
hun collega's in het bedrijfsleven die met succes de consumentenmarkt beïnvloeden of van veiligheidsinspecteurs die de werkomgeving op gevaren voor de gezondheid screenen. $\mathrm{Zij}$ hebben voor het beïnvloeden van de geestelijke volksgezondheid diverse veranderdeskundigheden ontwikkeld, gebaseerd op gedragswetenschappelijke kennis. Ze hebben het profiel van marketingsdeskundigen, risicoanalysten, gedragswetenschappelijke ontwerpers, makelaars in preventieprogramma's, en productieplanners. Ze vervullen rollen als voorlichter, trainer, beleidsadviseur en soms ook als lobbyist bij bedrijven, lokale overheden of sleutelfiguren, werken op basis van gestructureerde projectmodellen en staan open voor het toepassen van diverse vormen van kwaliteitscontrole. Het gaat hun niet om het uitbannen van geestesziekten maar om het realiseren van risicoreducties. Ook beperkte risicoreducties kunnen grote besparingen opleveren. Hun primaire effectdoelen op korte termijn betreffen het verminderen van risicofactoren en versterken van beschermende factoren. Van de thans uit onderzoek bekende factoren is in het recente preventierapport van het Amerikaanse Institute of Medicine, 'Reducing risks for mental disorder' een bruikbaar overzicht gepubliceerd. ${ }^{21}$

\section{De effectiviteit van pogingen tot beheersing}

Wat zeggen onderzoekers over de mogelijkheden tot het beheersen of tenminste beïnvloeden van de geestelijke volksgezondheid? Naar de beinvloedbaarheid van risicofactoren en beschermende factoren is de afgelopen vijfentwintig jaar een indrukwekkend geheel aan effectstudies uitgevoerd. Sinds mijn eerste uitspraken hierover tijdens het preventiecongres in 1987 en het boek 'Preventie op waarde geschat' zijn internationaal opnieuw enkele honderden effectstudies verschenen (Bosma \& Hosman, 1990). Ook in ons land is recentelijk een reeks van effectstudies afgerond. Ik denk daarbij met name aan de evaluatiestudies die door het Nederlands centrum Geestelijke volksgezondheid rond een aantal landelijke ontwikkelingsprojecten zijn uitgevoerd en de studies die door de Programmacommissie Determinanten van Gezondheid zijn geïnitieerd ${ }^{22}$.

\section{psychosociale weerbaarheid}

Wat eerder al was aangetoond is nu nog duidelijker geworden, preventieprogramma's zijn goed in staat de psychosociale weerbaarheid van men- 
sen te vergroten: een positiever zelfbeeld, meer zelfvertrouwen, vaardigheden in het hanteren van stresssituaties en conflicten, inzicht in het oplossen van problemen, sociale vaardigheden en het verbeteren van sociale steun.

Wat is de waarde van dit soort programma's? Ten eerste is hiermee aangetoond dat we tenminste in staat zijn om bepaalde elementen van geestelijke gezondheid te bevorderen ${ }^{23}$.

Het tweede belang is verstrekkender. Het is waarschijnlijk dat in de ontwikkeling van verschillende psychiatrische stoornissen voor een deel dezelfde factoren een rol spelen. Ze worden daarom wel non-specifieke risicofactoren of non-specifieke beschermende factoren genoemd ${ }^{24}$. Van deze non-specifieke factoren, voorzover in onderzoek aangetoond, zijn door Coie e.a. in the American Psychologist en door het Amerikaanse Institute of Medicine recentelijk overzichten gepubliceerd (Coie, Watt, West et al., 1993; Mrazek \& Haggerty, 1994). De zojuist genoemde weerbaarheidsfactoren vormen een onderdeel van deze lijst naast protectieve omgevingsfactoren, zoals sociale steun, een liefderijke opvoeding, sociale controle en de beschikbaarheid van preventief modelgedrag. Door dit soort factoren met succes te beïnvloeden kunnen risicoreducties worden gerealiseerd. Dit lijkt vooral zinvol bij groepen die een hoog risico lopen op psychische stoornissen, dus in groepen en situaties waar zich een cumulatie van risicofactoren of risicoprocessen voordoet. ${ }^{25} \mathrm{Bij}$ deze groepen worden doorgaans de meest duidelijke effecten gevonden bij het beïnvloeden van dergelijke factoren. Onderzoek zal moeten uitwijzen of deze interventies bij risicogroepen uiteindelijk ook tot aantoonbare reducties van psychische stoornissen leiden. Een belangrijk punt voor de komende researchagenda.

Als dit effect aangetoond kan worden, zijn we een heel eind op weg naar het meer beheersbaar maken van de geestelijke volksgezondheid. Immers, in tegenstelling tot de negatieve verwachtingen van Ormel hierover, blijkt het mogelijk deze programma's op grote schaal uit te voeren. Dat is althans de ervaring van onze Amerikaanse preventiecollega's. Een groot aantal van de door de National Mental Health Association beschreven 39 modelprogramma's worden inmiddels op landelijke schaal uitgevoerd en sommige zelfs op internationale schaal ${ }^{26}$. Veelal gaat het om implementaties binnen scholen of in opvoedingscircuits. Zo werd één modelprogramma, gericht op kinderen van gescheiden ouders, zelfs op 2500 
plaatsen in Canada en de Verenigde Staten uitgevoerd. Het JOBS-programma, ontwikkeld door Price en Vinokur van het Michigan Prevention Research Centre, wordt thans niet alleen op vele plaatsen in de VS, maar ook in Europa uitgevoerd. Effectieve programma's die in de zeventiger of tachtiger jaren ontwikkeld zijn treden nu de volgende fase binnen van de grootschalige implementatie. Cruciaal bij deze volgende stappen is dat ook in deze fasen opnieuw effectstudies worden uitgevoerd. Bewezen effectiviteit in experimentele testsituaties is nog geen garantie voor effectiviteit van een grootschalige uitvoering van hetzelfde programma op andere plaatsen. In de Verenigde Staten en Europa worden nu verscheidene 'multi-site' effect-studies uitgevoerd ${ }^{27}$.

\section{sociale risicofactoren}

Of het mogelijk is om ook sociale risicofactoren te beïnvloeden is lang een twijfelachtige zaak geweest. Inmiddels zijn ook voor deze factoren belangwekkende effecten van preventieprogramma's gevonden. $\mathrm{Zo}$ is in diverse studies aangetoond dat met behulp van oudervoorlichting en stressmanagement trainingen aan ouders kindermishandeling kan worden verminderd met tenminste 50\% (Olds, 1988; Barker, Anderson, Chalmers, 1992). Een ander voorbeeld: in een landelijke Noorse studie bleek het sociale klimaat op scholen dusdanig te kunnen worden beïnvloed dat het pestgedrag tot de helft kon worden verminderd (Olweus, 1992). De resultaten van dit onderzoek hebben ertoe geleid dat dit programma op initiatief van de Noorse overheid op nationaal niveau in de Noorse scholen is ingevoerd. Ook in diverse andere Europese landen, waaronder Nederland, wordt thans met de invoering van dit programma geëxperimenteerd. Voorts zijn aanwijzingen dat fysiek geweld binnen het huwelijk kan worden verminderd met behulp van preventieve maatregelen. Bij een meting 5 jaar na deelname aan een training in relatievorming en communicatie, bleek in de relaties van de deelnemende paren minder fysiek geweld voor te komen dan in een vergelijkbare controlegroep (Markman, Renick, Floyd et al., 1993). In de werksfeer blijkt door preventieve maatregelen de arbeidssatisfactie te kunnen worden verbeterd en daarmee het ervaren stressniveau verlaagd (Spaans \& Geelen, 1995). Als laatste voorbeeld kan een geslaagde preventieve actie in Australië worden genoemd om het geweld op de televisie terug te dringen. Veel geweld in TV-programma's blijkt de ontwikkeling van aggressief gedrag bij kinde- 
ren in de hand te kunnen werken. Gerichte onderhandelingen met de Australische media hebben geleid tot een aanzienlijke afname van geweld in TV-programma's, namelijk van gemiddeld 9.5 geweldsepisodes per uur in 1984 tot 4.3 geweldsepisodes per uur in 1989 (Abbott, 1991).

\section{depressieve symptomen en stoornissen}

Voorts blijkt dat het goed mogelijk is om via preventieprogramma's het aantal depressieve symptomen te verminderen. Dit is in een groot aantal studies bij adolescenten en volwassenen aangetoond. Een vermindering van het aantal depressieve symptomen is gevonden als resultaat van diverse typen van interventies, zoals cursussen in het omgaan met depressie, opvoedingsvoorlichting aan ouders, leefstijlprogramma's, stressmanagement trainingen, bibliotherapie, bewegingsprogramma's en ondersteuningsgroepen ${ }^{28}$. Ook in onze Nijmeegse studie naar invloed van de cursus Stemmingmakerij voor adolescenten met een verhoogd risico op depressie kon een reducerend effect op depressieve symptomen worden aangetoond (Veltman, Ruiter \& Hosman, 1996).

Als we in staat zijn via preventieprogramma's depressieve symptomen te verminderen heeft dat enige betekenis voor het uiteindelijk voorkómen van depresieve stoornissen? In een recente prospectieve studie van Horwath e.a. (1992) onder 9.900 volwassenen bleek dat mensen met een hoger niveau van depressieve symptomen een 4 tot 5 maal zo grote kans lopen om binnen 1 jaar voor het eerst een depressieve stoornis te ontwikkelen. Ook Lewinsohn heeft een vergelijkbare studie uitgevoerd waarin hij tot dezelfde conclusie kwam (Lewinsohn, Hoberman \& Rosenbaum, 1988). Dit maakt het aannemelijk dat het tijdig verminderen van depressieve symptomen via preventieve maatregelen, bijvoorbeeld door het verbeteren van iemand's psychosociale weerbaarheid, zou kunnen leiden tot minder nieuwe depressieve stoornissen. Recentelijk is dit voor het eerst aangetoond in een studie van Clarke e.a. (1995). Deelname aan een cursus 'Omgaan met depressie' leidde bij adolescenten met een hoog risico tot een aanmerkelijke vermindering van het aantal nieuwe gevallen van depressie binnen 1 jaar. Het risico daalde van $26 \%$ naar $14 \%$, een vermindering met bijna de helft $\mathrm{ft}^{29}$.

Over risicofactoren in de ontwikkeling van depressie is inmiddels al heel wat bekend ${ }^{30}$. Het is zeer waarschijnlijk dat bij de ontwikkeling van depressie de volgende psychologische en sociale risicofactoren een rol spe- 
len, namelijk kindermishandeling en emotionele verwaarlozing, vroegkinderlijke verlieservaringen (m.n. overlijden moeder), een ouder met een ernstige depressieve stoornis of verslaving, duurzame relationele problemen, dagelijkse problemen met een chronisch karakter, een negatief zelfbeeld, een neiging tot negatief denken, weinig probleemoplossende en sociale vaardigheden en een gebrek aan sociale steun. De meeste van deze factoren leidden ieder op zichzelf niet tot een depressieve stoornis of hebben daarop slechts een beperkte invloed. Het risico blijkt vooral verhoogd te worden wanneer factoren in combinatie met elkaar optreden $^{31}$. Wanneer via preventieve interventies tenminste een deel van deze factoren kan worden beïnvloed zou daarmee de kans op een cumulatie van risicofactoren worden verminderd en daarmee ook de kans op depressie.

Interessant is dat de meeste van de hier genoemde risicofactoren inmiddels inderdaad met succes via preventieve interventies beïnvloed kunnen worden. Soms zijn voor dergelijke programma's bovendien varianten uitgewerkt voor verschillende leeftijdgroepen of verschillende typen risicogroepen. Dit biedt voor het eerst het perspectief op het ontwerpen van een meer integrale preventiestrategie om depressie in de samenleving tegelijkertijd op meerdere fronten aan te pakken. Een dergelijke integrale aanpak lijkt mij een voorwaarde om op lange termijn aantoonbare reducties in depressie op bevolkingsniveau te realiseren. Het komt er dan op aan de meest effectieve en doelmatige combinatie van programma's te selecteren.

\section{preventie van andere psychische stoornissen}

Waar liggen nog meer kansen voor effectieve preventie van psychische stoornissen? Het is in het kader van deze rede niet mogelijk een volledig overzicht te geven van alle gevonden effecten in evaluatiestudies ${ }^{32}$ of om alle stoornissen uit de DSM-IV te bespreken. Ik beperk me hier tot enkele opmerkingen over een drietal kansrijke gebieden.

Allereerst lijkt mij de preventie van gedragsstoornissen en oppositioneelopstandig gedrag (ODD) bij kinderen en jongeren een belangrijk thema voor de nabije toekomst. Uit onderzoek blijkt dat jonge kinderen met gedragsproblemen en in het bijzonder met frekwent aggressief gedrag een hoog risico lopen op het ontwikkelen van chronisch antisociaal en gewel- 
dadig gedrag, jeugddelinquentie, alcohol- of drugsverslaving, langdurige werkeloosheid en verkeersongevallen, afhankelijkheid van sociale uitkeringen ${ }^{33}$. Deze risico's gelden in het bijzonder voor jongens. De hoogte van het risico op latere psychiatrische en sociale problemen blijkt afhankelijk van een veelheid aan risicofactoren, zoals onder meer gebrekkige opvoedingsvaardigheden bij ouders, kindermishandeling en verwaarlozing, antisociaal gedrag bij de vader, weinig probleemoplossende en sociale vaardigheden bij kinderen, weinig normatieve opvattingen over aggressief gedrag en slechte schoolprestaties. Uit diverse studies blijkt dat het mogelijk is om bij risicogroepen ernstige gedragsproblemen met behulp van primair- en secundair-preventieve interventies te voorkómen of ten minste belangrijke risicofactoren met succes te beïnvloeden ${ }^{34}$. Bij enkele programma's werd tevens een preventief effect op later delinquent gedrag aangetoond. In dergelijke preventieprogramma's wordt onder meer gebruik gemaakt van opvoedingsondersteuning in de vroege kinderjaren, vroegtijdige behandelingen van kinderen en multisysteem gerichte programma's aan het begin van de basisschool en rond de overgang naar het voortgezet onderwijs.

Er zijn in onderzoek aanwijzingen gevonden dat een vijandige en afwijzende houding van ouders en vroegkinderlijke mishandeling en verwaarlozing een hogere kans prediceert op de ontwikkeling van een antisociale persoonlijkheidsstoornis (Millon, 1981; Luntz \& Widom, 1994). Het zou daarom interessant zijn om te onderzoeken of het verminderen van kindermishandeling en verwaarlozing in de vroege kinderjaren in combinatie met de preventie van gedragsstoornissen zou kunnen bijdragen tot een lager risico op de ontwikkeling van persoonlijkheidsstoornissen.

De grootste winst ten aanzien van het terugdringen van de psychiatrische prevalentie is de komende jaren ongetwijfeld te realiseren via terugvalpreventie. Dit betekent het voorkómen van het opnieuw optreden van een stoornis bij iemand die daar al eerder last van heeft gehad. Een groot deel van de bestaande psychiatrische morbiditeit betreft mensen die al eerder een psychiatrische episode hebben doorgemaakt. Het kan darbij gaan om hetzelfde type stoornis of een andere stoornis. Zo is de kans op terugval bij depressie in engere zin ongeveer $50 \%$ binnen twee jaar en na vijf jaar zelfs $76 \%$ (Keller, 1988). Mensen met een depressieve stoornis hebben niet zelden eerder een andere stoornis gehad, bijvoorbeeld een angststoor- 
nis of een verslaving. In een studie van Rohde, Lewinsohn \& Seeley (1991) bleek dit bij $42 \%$ van depressieve adolescenten het geval en bij $25 \%$ van de depressieve volwassenen. ${ }^{35}$ Dit betekent dat ook de groep van huidige psychiatrische patiënten en niet behandelde cases een belangrijke doelgroep vormt voor preventieve interventies.

Bij depressies kan terugval onder meer voorkómen worden door het gebruik van cognitieve gedragsbenaderingen tijdens de voorgaande episode, of door aan de therapie een kort programma toe te voegen waarin mensen geleerd wordt hoe ze in de toekomst herhaling kunnen voorkómen. Een goede illustratie van een dergelijk aanvullend trainingsprogramma wordt beschreven in een recente Duitse studie. Kuhner et al. (1994) toonden aan dat het aantal gevallen van hernieuwd optredende depressies door deelname aan dit programma met tweederde kon worden verminderd.

Over de mogelijkheden om terugval bij schizofrene patiënten te voorkomen is inmiddels al veel bekend. Een recente overzichtsstudie van Goldstein (1994) laat zien dat door middel van gezinsgerichte interventies bestaande uit psychoeducatie, het aanleren van probleemoplossende vaardigheden en het bevorderen van trouw medicatiegebruik aanzienlijke reducties in terugval kunnen worden bereikt. In de door Goldstein besproken vijf effectstudies daalde de kans op terugval van gemiddeld 40 à $50 \%$ binnen 9 maanden naar minder dan $10 \%$.

Verder kunnen preventieve effecten voor de geestelijke volksgezondheid verwacht worden van interventies die primair gericht zijn op voorkóómbare lichamelijke aandoeningen en fysieke risicofactoren. Ik denk daarbij met name aan rode hond, regelmatig gebruik van alcohol, drugs en medicijnen tijdens de zwangerschap, geboortecomplicaties, loodvergiftiging, hersenletsel door ongevallen en hoge bloeddruk. $\mathrm{Zij}$ vormen bekende risicofactoren in de ontwikkeling van psychopathologie, onder meer doordat zij een schadelijke invloed hebben op de ontwikkeling en het functioneren van hersenen en zenuwstelsel. Zo is bekend dat hoge bloeddruk en hart- en vaatziekten een risico in op multi-infarct dementie inhouden. De genoemde risicofactoren worden thans met succes beïnloed door interventies en maatregelen die buiten het directe werkveld van de ggz-preventie liggen, zoals door milieumaatregelen (loodvergiftiging), verkeersveiligheid (hersenletsel), verbeteringen in zwangerschapbegeleiding en perinatale zorg (geboortecomplicaties), preventie van hart- en vaatziekten en 
preventie van alcohol- en drugsverslaving.

Samengevat. kunnen we allereerst concluderen dat ggz-preventie inderdaad effectief kan zijn en dat een bescheiden perspectief begint te groeien om op termijn de risico's op psychische stoornissen enigszins te beheersen. Bovendien bieden de beïnvloedbare non-specifieke factoren een perspectief om de oorspronkelijke welzijnsbenadering en de huidige psychiatrische oriëntatie, dus de bevordering van geestelijke gezondheid en de preventie van psychische ziekten, op een produktieve wijze met elkaar te combineren. Ervaringen in het buitenland leren bovendien dat het mogelijk is succesvolle preventieprogramma's op grote schaal ingevoerd te krijgen. Kortom, voor een fundamentele skepsis ten aanzien van het mogelijkheid van effectieve ggz-preventie lijkt mij geen grond te bestaan.

\section{Management van effectieve preventie}

Dan nu de beheersbaarheid van de preventiesector zelf. Bij het ontwikkelen van nieuwe preventieprogramma's en het implementeren van die programma's in de samenleving gaat het om uiterst complexe processen. Hierover is door niet-preventiewerkers in de geestelijke gezondheidszorg altijd tamelijk simplistisch gedacht. Dat leidde in de RIAGG's soms tot zinloze oekazen van managers in de trant van: maak iets moois, doe daar niet te lang over, schrijf vooral geen lange analyserapporten en projectplannen, maar ga zo snel mogelijk aan de slag met iets concreets, bijvoorbeeld een cursus of groep, en lever vooral een hoge produktie. Dat is een werkmodel dat mogelijk past op een gevestigde behandelingssector, maar niet op een zich ontwikkelend vakgebied als de preventie. Daar werkt het contraproduktief op de effectiviteit en leidt alleen tot schijndoelmatigheid.

Het zijn niet zozeer de preventiewerkers die van hun bazen een cursus in management en doelmatig handelen zouden moeten krijgen, maar juist de ggz-managers die het aan kennis omtrent fundamentele preventieprocessen ontbreekt. Dit blijkt regelmatig een bron te vormen voor spanningen tussen instellingsmanagement en preventiewerkers en een ernstige barrière voor de ontwikkeling van effectieve ggz-preventie. Ik ben dan ook van mening, dat een inleiding in de geschiedenis en grondbeginselen van ggzpreventie en in het management van effectieve preventie een verplicht 
onderdeel zou moeten uitmaken van de scholing en nascholing van managers in de geestelijke gezondheidszorg.

Aan de andere kant is er ook veel terechte kritiek geweest op de wijze waarop Preventie Nederland haar werk de afgelopen 25 jaar georganiseerd heeft: versnipperd, geen prioriteiten, te modegevoelig, geen continuiteit, geen epidemiologisch fundament, weinig aandacht voor effect en efficiency.

Deze kritieken hebben de afgelopen jaren tot duidelijke koerswijzigingen geleid in de richting van een meer doelmatige preventiepraktijk. Zowel 25 jaar ggz-preventic in Nederland als het vele preventiewerk en preventieonderzoek in het buitenland hebben een aantal bruikbare inzichten opgeleverd over de wijze waarop management van effectieve preventie eruit zou moeten zien. Landelijke ontwikkelingsprojecten, effectstudies en aandacht voor kwaliteitsbeheersing zijn hiervan voorbeelden. Zo wordt er gewerkt aan het samenstellen van lijsten met praktische aanwijzingen die kunnen bijdragen tot verhoging van de effectiviteit van het preventiewerk ${ }^{36}$. Enkele voorbeelden van dergelijke aanwijzingen: selecteer bij voorkeur doelgroepen met de hoogste risico's, met name groepen waarbij zich een cumulatie van risicofactoren dreigt voor te doen; breek een doelgroep op in segmenten zodat ieder segment meer naar behoefte kan worden bediend; maak gebruik van een zorgvuldig geselecteerde combinatie van interventies om eenzelfde preventief einddoel te bereiken (multicomponent benadering), kleine afzonderlijke interventies zijn daartoe meestal onvoldoende; intervenieer in perioden vóórdat risicofactoren zich hebben gestabiliseerd; preventie is effectiever als interventies zich niet alleen op de doelgroep zelf richten maar ook op de sociale systemen waarmee de doelgroep dagelijks te maken heeft; zorg dat een preventieprodukt niet alleen geestelijke gezondheidswinst oplevert maar ook andere soorten winst die voor de doelgroep of de financier aantrekkelijk zijn, dit zal de motivatie tot participatie en inzet aanzienlijk vergroten.

Om een effectieve preventiepraktijk te kunnen ontwikkelen is het essentieel dat alle krachten en voorzieningen die daarvoor nodig zijn doelmatig op elkaar worden afgestemd. Dat is op dit moment zeker niet het geval. Bijvoorbeeld onderzoek, programmaontwikkeling in de praktijk en deskundigheidsbevordering worden niet gecoördineerd ingezet voor landelijke prioriteiten omdat daarover tussen partijen geen afspraken worden gemaakt. Ook in de preventiepraktijk bestaat inmiddels grote behoefte aan 
landelijke coördinatie. Een Nationale Commissie zou een realistisch Nationaal Plan voor de ggz-Preventie kunnen uitwerken met duidelijke prioriteiten en voorwaarden voor een meer optimale afstemming. Vandaaruit zou gewerkt kunnen worden aan het tot stand brengen van concrete convenanten tussen partijen, zoals de financiers, werkgevers van verschillende typen praktijkorganisaties, de beroepsvereniging, opleidingsinstituten, ondersteuningsinstituten en toekomstige afnemers van preventieprogramma's. In dergelijke convenanten kunnen gezamelijke prioriteiten worden vastgelegd en overeenkomsten worden gesloten over onderlinge afstemming, financieringsstromen, taakverdelingen, doelmatige onderlinge dienstverlening, gezamelijke projecten en lange termijn trajecten voor de ontwikkeling en brede implementatie van specifieke preventieprogramma's.

Voor het ontwikkelen van een breed scala aan effectieve programma's beschikt Nederland over te weinig capaciteit. Daarvoor is internationale samenwerking onmisbaar. Op het gebied van de ggz-preventie bestaan inmiddels diverse internationale ontwikkelingsnetwerken, waarin ook door ons land wordt geparticipeerd. Dat geldt onder meer voor de preventie van depressie en gezondheidsbevordering in scholen. Daarnaast dient de internationale markt voor elders ontwikkelde en effectief gebleken programma's beter toegankelijk gemaakt te worden. Recentelijk is de Europese commissie bereid gevonden hiervoor een Europees netwerk van informatiepunten te financieren, met elkaar verbonden in één computersysteem ${ }^{37}$.

Tot zover enkele eerste contouren voor een doelmatiger management van preventie.

\section{Preventiewetenschap}

Op basis van het vele onderzoek naar risicofactoren en de talrijke studies naar de effecten van preventieve interventies is zich thans op het terrein van de geestelijke gezondheid een preventiewetenschap aan het ontwikkelen. In de American Psychologist van october 1993 heeft een groep van toonaangevende Amerikaanse onderzoekers daarvan de contouren beschreven $^{38}$. Op basis hiervan is voor het National Institute of Mental Health een Nationaal Onderzoeksprogramma voor Preventie ontwikkeld $^{39}$. Dit onderzoeksprogramma is ook voor Nederland en Europa in- 
spirerend, enerzijds omdat een dergelijk onderzoeksbeleid hier überhaupt ontbreekt, anderzijds vanwege haar bijzondere inhoud. Het bevat een integrale visie niet alleen over onderzoeksprioriteiten, maar ook over zaken als de ontwikkeling van wetenschappelijk talent, interdisicplinair onderzoek en leiderschapsfuncties in preventieonderzoek. Dat zijn zaken die ook in ons land voor een beter management van effectieve preventie onmisbaar zijn. Een gunstige gelegenheid doet zich thans voor nu de Raad voor het Gezondheidsonderzoek onlangs in haar Nota Prioriteiten voor Preventieonderzoek onderzoek het gebied van de preventie van psychische ziekten als een belangrijke prioriteit heeft aangemerkt ${ }^{40}$.

Wat de Amerikaanse preventieonderzoekers betreft is het opvallend dat er in de Verenigde Staten nauwelijks banden bestaan tussen wetenschappers op het terrein van 'health education' en 'health promotion' en preventiewetenschappers op het gebied van de geestelijke volksgezondheid. Het blijken wonderlijk genoeg geheel gescheiden ontwikkelingsgebieden, waartussen geen kruisbevruchting plaatsvindt. Gezien de noodzaak van snellere voortgang bij het ontwikkelen van wetenschappelijke kennis over effectieve preventie, is deze situatie onwenselijk. In Nederland en met name in Maastricht verkeren wij door de nauwe banden tussen de gvosector en de ggz-preventie, in een unieke situatie om die relatie wél te leggen.

Zo is er op het terrein van de gezondheidsvoorlichting veel kennis voorhanden over beïnvloeding van gezondheidsgedrag en implementatieprocessen die binnen de ggz-preventie nog weinig wordt toegepast. Dat zelfde geldt voor kennis over informatieverwerking en massamediale beïnvloeding. Anderzijds is de preventie op het terrein van de geestelijke gezondheid vanouds sterk gebaseerd op theorieën over stress en coping en over de preventieve invloed van sociale steun. In de de gvo-sector is voor deze theorieën pas zeer recentelijk aandacht ontstaan. In de zich ontwikkelende wetenschap van de ggz-preventie spelen bovendien de ontwikkelingspsychopathologie en ontwikkelingsepidemiologie een belangrijke rol. $\mathrm{Zij}$ bieden inzicht in de temporele ontwikkeling van risicofactoren en beschermende factoren en hun onderlinge wisseiwerking. ${ }^{41}$ Voor het kiezen van de meest geschikte tijdstippen of perioden voor effectieve interventie is dergelijke kennis onmisbaar.

Zowel binnen de gvo-wetenschap als in de preventiewetenschap wordt de 
laatste jaren gewerkt aan de ontwikkeling van kennis over determinanter. van effectiviteit. Het zou de ontwikkeling van een theorie over effectiviteit en effectmanagement zeer ten goede komen wanneer wetenschappers vanuit beide sectoren hun kennis hierover systematisch zouden uitwisselen en integreren.

Een dergelijke uitwisseling is overigens niet alleen nodig tussen wetenschappers onderling, maar ook tussen wetenschappers en praktijkwerkers $^{42}$. Er zijn door praktijkwerkers de afgelopen 25 jaar veel praktijkinzichten ontwikkeld die nog weinig gesystematiseerd zijn, bijvoorbeeld op het terrein van implementatieprocessen. Dit staat niet alleen de verspreiding van deze praktijkkennis, maar ook de wetenschappelijke toetsing ervan in de weg.

Samenwerking tussen verschillende groepen van wetenschappers is ook uit efficiëncy-oogpunt van belang. Een voorbeeld hiervan is de samenwerking met onderzoekers op het terrein van de experimentele psychopathologie. Waarom zouden wij niet als onderzoeksbeleid kiezen om experimenteel therapieonderzoek systematisch te koppelen aan preventieonderzoek. In therapieonderzoek wordt vaak gebruik gemaakt van placebocondities of condities waarin 'spontaan herstel' vergeleken wordt met de effecten van therapeutische interventies. Binnen deze condities kan via prospectieve beloopstudies nagegaan worden, waarin personen zich onderscheiden die kennelijk in staat zijn om zonder therapeutische hulp, dus op eigen kracht of met steun van hun directe omgeving hun psychische problemen en klachten te overwinnen. Dit onderzoek kan belangrijke informatie bieden over de factoren die preventief versterkt zouden kunnen worden om de psychosociale veerkracht van mensen te vergroten. ${ }^{43}$ Daarnaast kan dit onderzoek belooppredictoren opleveren, die gebruik kunnen worden om de werkelijke behoefte aan secundaire preventie en psychotherapeutische hulp beter in te schatten. Gebruik hiervan in de huisartspraktijk kan een meer verantwoord verwijsbeleid opleveren en dienen als een instrument om de vraag naar gespecialiseerde hulp te beperken (zorgpreventie).

Kruisbevruchting tussen wetenschappelijke kennis over gezondheidsvoorlichting en ggz-preventie, tussen de formele kennis van wetenschappers en de ervaringskennis van praktijkwerkers, en tussen de preventieweten- 
schap en de experimentele psychopathologie zullen belangrijke agendapunten vormen in het kader van deze leeropdracht. Dergelijke kruisbevruchtingen kunnen de ontwikkeling van fundamentele kennis over preventie versnellen en daarmee ook het perspectief op het realiseren van preventieve effecten.

\section{Financiering}

Preventie kost geld, en meer investering in preventie kost uiteraard meer geld. De afgelopen 10 jaar zijn er relatief weinig extra middelen in ggzpreventie geïnvesteerd. In de RIAGG's is de capaciteit zelfs iets teruggelopen $^{44}$. Om de bereidheid tot investering te verbeteren is niet alleen meer inzicht in de effecten van preventieve interventies nodig, maar ook een meer zakelijke manier van kijken tegen kosten en rendement van preventie.

Om het denken hierover te stimuleren wil ik $u$ een tweetal ruwe calculaties niet onthouden. De voorbeelden maken duidelijk hoezeer met zeer beperkte risicoreducties door preventie, ruim voldoende budget vrijkomt om de preventiesector te financieren en zelfs uit te breiden.

Allereerst een voorbeeld uit de forensische psychiatrie. Een TBS-patiënt, dus een delinquent met een doorgaans ernstige psychische stoornis, verblijft gemiddeld 5 jaar in een TBS-kliniek à raison van $f$ 900,- per $\mathrm{dag}^{45}$. Daar komen nog een grote reeks andere kosten bij voorafgaande en gedurende de TBS-periode ${ }^{46}$. Een conservatieve schatting komt uit op een kostenplaatje van ten minste 3 miljoen. Stel dat wij door de volledige inzet van alle RIAGG-preventiewerkers in Nederland jaarlijks bij 10 mensen een carrière zouden kunnen voorkómen die van ernstige verwaarlozing en mishandeling tijdens de kinderjaren, problematisch opvoedingsgedrag, gedragsproblemen en gedragsstoornissen, jeugddelinquentie uiteindelijk leidt tot een misdrijf met TBS-veroordeling. Dat is anno 1996 een risicoreductie van 5 à $6 \%$. Dat zou een besparing opleveren van 30 miljoen. Hiervan zouden we in Nederland gedurende een heel jaar de totale personeelskosten van alle preventiewerkers (216) en preventieteams bij de 57 RIAGG's kunnen bekostigen. Daar bovenop zouden we met deze besparing het preventiepotentieel nog eens met ruim 100\% kunnen uitbreiden.

Een tweede voorbeeld. Stel dat we aantoonbaar in staat zouden jaarlijks 
bij 100 mensen een arbeidsongeschiktheid op psychische gronden te voorkomen met een gemiddelde wao-duur van vijf jaar. Dat levert een besparing op van 40 miljoen. Hieruit zuden we het hele preventiepotentieel niet alleen bij de RIAGG's maar ook bij de GGD-en kunnen betalen en daarbovenop het preventiepotentieel nog met $40 \%$ kunnen uitbreiden. Om deze winst binnen te halen hoeven we in een jaar slechts een risicovermindering van nog geen $0,4 \%$ procent te realiseren ${ }^{48}$. Ook diverse buitenlandse kosten-baten studies tonen aan dat investeringen in de ggzpreventie zich vele malen kunnen terugverdienen ${ }^{49}$. Om op een realistische wijze over investeringen in ggz-preventie te kunnen praten is van groot belang om in de nabije toekomst ook economen bij de ontwikkeling van ggz-preventie en het evaluatieonderzoek te betrekken.

\section{Plaats van preventie in de geestelijke gezondheidszorg}

Dames en Heren, aan het einde van dit betoog wil ik graag nog iets zeggen over de plaats van preventie binnen de geestelijke gezondheidszorg. Een heldere, stabiele en centrale plaats van preventie binnen de GGZinstellingen is een noodzakelijke randvoorwaarde voor het kunnen ontwikkelen van effectieve preventie. Ik ben van mening dat 'preventie' een onlosmakelijk onderdeel dient te zijn van het 'mission statement' van iedere ggz-organisatie. Dat geldt niet alleen voor de RIAGG's, waar preventie reeds is opgenomen in de erkenningsvoorwaarden. Het lijkt me noodzakelijk dat in de nabije toekomst ook aan de psychiatrische ziekenhuizen, kinder- en jeugdpsychiatrische instellingen en forensischpsychiatrische voorzieningen een formele preventietaak wordt toegekend. Hun expertise met betrekking tot de ontwikkeling van ernstige psychiatrie is tot nu toe nog nauwelijks benut om daar preventieve winst uit te halen, terwijl hier naar mijn verwachting grote kansen liggen.

Het is wat dit betreft uiterst bemoedigend dat recentelijk de eerste preventiewerker in een psychiatrisch ziekenhuis is aangesteld en wel in het oudste psychiatrische ziekenhuis van Nederland, het Reinier van Arkel, weliswaar pas 556 jaar na de oprichting ervan.

Zorgelijk is aan de andere kant dat sommige RIAGG-managers overwegen of het misschien niet beter zou zijn om de preventie-functie uit de RIAGG weg te schrijven. Zoals ik eerder heb toegelicht behoort preventie tot de fundamenten van de ambulante geestelijke gezondheidszorg. 
Het is uiterst verontrustend dat bij de huidige fusiebesprekingen in de GGZ preventie in veel gevallen een non-item is. Het gevaar is levensgroot dat in de nieuwe organisatiemodellen preventie geheel uit het besluitvormingsproces van de GGZ-instellingen verdwijnt ${ }^{50}$. Preventie dreigt steeds verder naar de marge van de GGZ op te schuiven: Noch kop, noch munt, maar 'Preventie zij met ons' op de rand van de ggzgulden. Dat lijkt mij een onaanvaardbare situatie.

Voorkómen moet worden dat het aanbod van de RIAGG's en de nieuwe gefuseerde GGZ-instellngen steeds meer een mono-cultuur wordt van individueel behandelen en begeleiden. Ik wil ervoor pleiten dat de RIAGG's zich bij de vorming van de nieuwe GGZ-instellingen weer meer oriënteren op hun 'roots': het gedachtengoed van de geestelijke volksgezondheid en de psychohygiëne, waarop ook het oorspronkelijke RIAGG-model geënt was.

Functionele spanning. Over de afgelopen 150 jaar heeft de geestelijke gezondheidzorg zich steeds meer in preventieve richting ontwikkeld. Het opzetten van een ambulante zorg, beschermde woonvormen, arbeidsrehabilitatie voor patienten, vroege diagnostiek, het versterken van de ggzfunctie in de eerste lijn en de huidige PIT-projecten ${ }^{51}$ zijn hiervan duidelijke voorbeelden. Deze ontwikkeling naar meer preventie is een onomkeerbaar proces.

De aanwezigheid van curatie én preventie in ggz-instellingen is niet alleen uit historische, gezondheidspolitieke en ethische overwegingen te rechtvaardigen, de spanning die veelal tussen preventie en curatie bestaat is voor de kwaliteit van beide functioneel. Het is een dynamische spanning die het bedrijf als geheel ten goede komt, mits managers en praktijkwerkers van deze spanning op een produktieve wijze gebruik weten te maken. Voor de kwaliteit van het preventiewerk is het van essentieel belang dat het zich laat inspireren en controleren door wat de curatieve zorg aan niet-voorkómen psychisch lijden onder ogen krijgt, én door de kennis van hulpverleners over ziektegeschiedenissen. Voor de kwaliteit van de curatieve zorg is het van belang om voortdurend na te gaan of in het kader van de programmatische hulpverlening alle kansen worden benut om op een zo preventief mogelijke wijze hulp te verlenen, bijvoorbeeld door in behandelingsprogramma's meer aandacht voor terugvalpreventie in te bouwen, door het meer grootschalig toepassen van biblio- 
therapie of door extra preventieve zorg aan kinderen van patiënten te geven. Op deze wijze kunnen ggz-instellingen zich ontwikkelen tot multifunctionele regionale expertise-centra op het terrein van de geestelijke volksgezondheid.

Regional expertise-centrum. De uitdaging voor dit soort multifunctionele instellingen is om zich periodiek steeds af te vragen: hoe kunnen wij als expertisecentrum met gebruik van de meest recente wetenschapppelijke kennis en interventiemogelijkheden op het terrein van behandeling, begeleiding en preventie het meest effectieve en meest doelmatige antwoord geven op de geestelijke volksgezondheidsproblematiek in de regio?

Om op een produktieve wijze van deze functionele spanning tussen curatie en preventie gebruik te kunnen maken, is het van belang dat de preventiesector binnen de GGZ een duidelijk eigen gezicht behoudt en ruimte krijgt haar eigen expertise optimaal te ontwikkelen. Dat partners hun eigen identiteit kunnen behouden en ontwikkelen, is voor elke gezonde relatie is van belang. Dit principe geldt niet alleen voor cliënten van de ggz, maar ook voor de relatie tussen preventieve en curatieve zorg.

Het schuiven van preventie naar de marge van de ggz-instellingen en het integreren van preventiewerkers in curatieve teams werkt mogelijk als een korte termijn oplossing voor de problematische relatie tussen preventie en curatie, op de lange termijn bezien is het een kortzichtige oplos$\operatorname{sing}^{52}$. Voor een geestelijke gezondheidzorg die in staat wil zijn op termijn de onbeheersbaarheid van psychisch lijden terug te dringen is het essentieel dat zowel regionaal als landelijk de beide polen van de oorspronkelijk geestelijke volksgezondheidsbenadering meer met elkaar in evenwicht worden gebracht.

Dat was de eerste 80 jaar van deze eeuw nauwelijks mogelijk ondanks de vele mooie psychohygiënische gedachten over preventie en geestelijke gezondheidsbevordering. Lange tijd ontbrak het aan de meest fundamentele epidemiologische kennis, aan kennis over risicofactoren, aan goed opgeleide preventiedeskundigen, aan wetenschappelijke modellen over gedragsbeïnvloeding en sociale beïnvloeding en aan methodologie om de aanwezigheid of afwezigheid van effecten zichtbaar te maken. In zekere zin was preventie een idee dat te vroeg kwam. Dat was vaak frustrerend en heeft de associatie van preventionisten met illusionisten opgeroepen. Ik hoop u te hebben duidelijk gemaakt dat die situatie inmiddels fundamen- 
teel aan het veranderen is.

We dienen overigens ook nu niet de fout te maken van een overtrokken optimisme en het is raadzaam om onze preventieve doelen voorlopig bescheiden te houden. Maar of het optimisme dat op dit moment verantwoord lijkt ook in de komende decennnia bewaarheid wordt, zal afhangen van de beslissingen die wij op korte termijn zullen moeten nemen, beslissingen over de plaats van preventie, over de beheersbaarheid van de preventiesector en over investeringen in onderzoek en ontwikkeling.

Parafraserend op de bespiegelingen van Schnabel in de 'Weerbarstige geestesziekte' gaat het hierom: In de $19 \mathrm{e}$ eeuw was het dominante antwoord van de samenleving op psychiatrische zjekten: opsluiten en verzorgen. Het meest dominante antwoord in de twintigste eeuw is ongetwijfeld: behandelen en begeleiden. Of het dominante antwoord in de 21 ste eeuw preventie kan worden is niet alleen een kwestie van het doen van voorspellingen, maar evenzeer een kwestie van politieke keuzen, keuzen die nog in de 20 ste eeuw gemaakt dienen te worden over de ontwikkeling en implementatie van effectieve programma's en over de lange termijninvesteringen die daarvoor nodig zijn. Als dat gebeurt zal het jaar 2000 toch een belangrijke mijlpaal worden in de geestelijke volksgezondheid, ook al zouden belangrijke gezondheidsdoelen uit de 'Health for All by the year 2000' (WHO, 1984) niet gehaald worden.

"Ooit zal er een dag aanbreken dat er iets wordt uitgevonden om een volledige en ongeneeslijke psychische ineenstorting te voorkomen" schreef Clifford Beers 90 jaar geleden in zijn dagboek. Die dag was gisteren, die dag was vandaag, die dag kan morgen zijn of overmorgen. 


\section{Meneer de Rector Magnificus, Dames en Heren}

Aan het einde van mijn rede wil ik graag enkele woorden van dank uitspreken. Allereerst een woord van dank aan het College van Bestuur van de Rijksuniversiteit Limburg en het bestuur van de Faculteit der Gezondheidswetenschappen. $U$ zult begrepen hebben dat $\mathrm{ik} \mathrm{mij}$ in de Maastrichtse Universiteit, met haar multidisciplinaire gezondheidsbenadering en haar internationale oriëntatie thuisvoel. De mogelijkheden van uw universiteit voor kruisbevruchting met andere vakgebieden, in het bijzonder de gezondheidsvoorlichting, de experimentele psychopathologie, psychiatrie en de economie van de gezondheidszorg zijn voor de ontwikkeling van een preventiewetenschap van essentieel belang.

Geachte bestuursleden van de Nederlandse Vereniging voor Preventie en GVO en de Wetenschappelijke Stichting NVPG, in het bijzonder Gerard Molleman en Willem de Regt. Ik wil u van harte feliciteren met de instelling van deze leeropdracht. Het maakt duidelijk dat u terecht grote waarde hecht aan de wetenschappelijke fundering van preventieve geestelijke gezondheidszorg, en aan het belang van en integratie tussen gvo en ggzpreventie.

Daines en heren bestuursleden van het Nationaal Fonds voor de Geestelijke Volksgezondheid, in het bijzonder waarde Dijkhuis, beste Jos, ik beschouw het Nationaal Fonds als een van de belangrijkste promotors van het gedachtengoed van de psychohygiëne en de geestelijke volksgezondheid. De preventiesector op het terrein van de geestelijke gezondheid is u zeer erkentelijk voor de steun die $u$ heeft gegeven om de instelling van deze leerstoel mogelijk te maken. In de traditie van de psychohygiëne zal ik trachten een krachtig promotor te zijn van zowel de preventie als het preventieonderzoek.

Waarde Kok, beste Gerjo. Ik verheug me zeer op de voortzetting van onze jonge samenwerking. Als uitmuntend onderzoeker en wetenschappelijk publicist ben je voor mij een belangrijke inspiratiebron. Het opbouwen van een wetenschappelijk expertisecentrum van internationale faam is niet alleen voor wetenschappers interessant, maar ook voor de 
ontwikkelingskansen van de preventiepraktijk essentieel. Je initiatief om preventie en gezondheidsvoorlichting meer te integreren steun ik van harte.

Waarde collega's van de Vakgroep Gezondheidsvoorlichting. Met een parttimer als ik, die 's maandags na drie uur reizen als een schicht zijn kamer binnen schiet, is het niet makkelijk een relatie op te bouwen. Ik hoop dat na deze promotie het echte debat van start kan gaan over de verschillen en overeenkomsten in de wetenschappelijke fundering van gezondheidsvoorlichting en ggz-preventie.

Waarde collega's van het eerste uur, in het bijzonder Hans Hagendoorn, Henk Verburg, Ton van den Berg, Hans Saan en Hanneke van Doorm, juist op een dag als vandaag dient grote waardering uitgesproken te worden voor jullie jarenlange inzet voor de maatschappelijke erkenning en de kwaliteit van de ggz-preventie. Na duizenden commissievergaderingen in de afgelopen 25 jaar is er nog steeds een lange weg te gaan. Ik reken op jullie blijvende steun en inzet.

Waarde preventiewerkers en gvo-functionarissen. Ik beschouw de instelling van deze leerstoel als een belangrijke erkenning van het vele werk dat jullie de afgelopen 25 jaar in GGD-en, RIAGG's, CAD's en vele andere instellingen hebben verzet, vaak onder moeilijke omstandigheden. Ik zal mij inspannen met jullie dit vakgebied een stevig verankerde plaats te geven zowel in de wetenschap als in brede veld van de gezondheidszorg. Voor effectieve preventie is intensieve samenwerking tussen wetenschap en praktijk van essentieel.

Zeer gewaardeerde collega's van de Vakgroep Klinische psychologie en Persoonlijkheidsleer en de Researchgroep Preventie en Psychopathologie, waarde van der Staak, waarde Hoogduin, waarde Veltman, beste Cees en Kees, beste Nine. Al 25 jaar is de vakgroep mijn bakermat voor het ontwikkelen van preventie. Mijn samenwerking met jullie is voor mij van grote waarde. Mijn aanwezigheid in Maastricht zal tot meer kwaliteit in Nijmegen leiden.

Lieve Felix, voor mij ben jij vandaag een van de belangrijkste gasten. Ik herinner me dat je drie jaar was en naar de vele papieren en boeken in 
mijn studeerkamer keek en riep: preventie, preventie, preventie. Als er iemand in Nederland is die van kinds af aan met dit begrip vergroeid is geweest ben jij het wel.

Lieve Anja, jij bent de afgelopen jaren niet alleen mijn partner maar ook mijn persoonlijke preventiewerker geworden. Jij weet daarom als geen ander hoe moeilijk effectieve preventie is. Jouw bijzondere persoonlijkheid en vakkennis zijn voor mij een belangrijke inspiratiebron en zeer bevordelijk voor mijn geestelijke gezondheid.

Ik heb gezegd. 


\section{Literatuur}

Abbott, M.W. (1991). Television violence: A proactive prevention campaign. In G. Albee, L. Bond \& T. Cook Monsey (Eds.), Improving children's lives. Newbury Park: Sage.

Adler, A. (1904). Der Artz als Erzieher. Aerzrl. Standeszeinung, 3(13), 4-6; (14)), 3-4; (15), 4-5.

Barker W., Anderson R. \& Chalmers C. (1992). Child protection; the impact of the child development programme. University of Bristol: Early Childhood Development Unit.

Beers, C.W. (1908). A mind that found itself. New York: Longman, Green \& Company.

Beers, C.W. (1929). A mind that found itself. New York: Doubleday \& Company (Reprint with additions).

Berrueta-Clement J.R., Schweinhart L.J., Barnett W.S., Epstein A.S. \& Weikart D.P. (1984). Changed lives: the effects of the Perry Preschool Program on youths through age 19. Ypsilanti, Michigan: High/Scope Press.

Bloom \& Hodges (1988). The Colorado separation and divorce program: a preventive intervention program for newly separeted persons. In R.H. Price, E. L. Cowen, R.P. Lorian \& J. Ramos-McKay (Eds), 14 ounces of prevention: a casebook for practioners. Washington: American Psychological Association.

Bosma, M.W.M., \& Hosman, C.M.H. (1990). Preventie op waarde geschat. Nijmegen: Bêta.

Bosma, M.W.M., Hosman, C.M.H., de Vries, W.J. \& Veltman, J.E. (1994). Ontwikkelen van preventieprogramma's: praktijk als bron van kennis. Nijmegen: Vakgroep Klinische Psychologie en Persoonlijkheidsleer, KU Nijmegen.

Brown, G.W. (1992). Life events and social support: possibilities for primary prevention. In R. Jenkins et al., The prevention of depression and anxiety. London: HSMO.

Bijstra, J.O., van der Kooi, H.P., \& Oostra, L. (1995). Interventies in de psychosociale ontwikkeling van adolescenten. In R. Sanderman, W.J.A. van den Heuvel \& B. Krol (Red.). Interveniëren in determinanten van gezondheid: resultaten van een onderzoeksprogramma. Assen: Van Gorcum.

Cicchetti, D., \& Toth, S.L. (Eds.) (1992). Developmental perspectives on depression. Rochester, N.Y.: University of Rochester Press.

Clarke, G., Hawkins, W., Murphy, M., \& Sheeber, L. (1995). School-based primary prevention of depressive symptomatology in adolescents: Findings from two studies. Journal of Adolescent Research, 8, 2, 183-204. 
Coie, J.D., Watt, N.F., West, S.G., Hawkins, J.D., Asarnow, J.R., Markman, H.J., Ramey, S.L., Shure, M.B., \& Long. B. (1993). The science of prevention. American Psychologist. 48, 10, 1013-1022.

Cuijpers, W.J.M.J. (1993). De werking van ondersteuningsgroepen voor centrale verzorgers van dementerende ouderen. Akademisch Proefschrift, Katholieke Universiteit Nijmegen.

Cuijpers, W.J.M.J. (1995). Psychoeducatie als behandeling van unipolaire depressies Tijdschrift voor Psychiatrie, 38, 7, 545-557.

Cuijpers, W.J.M.J. (1995). Bibliotherapie bij unipolaire depressies: een metaanalyse. Tijdschrift voor Gedragstherapie, 28,4, 279-295.

Daamen, J., \& van Mierlo, H.A.J. (1995). De effecten van een taakherverdeling binnen een IVBO/VBO/MAVO-onderwijsorganisaties op het ervaren van stress en burnout. In R. Sanderman, W.J.A. van den Heuvel \& B. Krol (Red.). Interveniëren in determinanten van gezondheid: resultaten van een onderzoeksprogramma. Assen: Van Gorcum.

Durlak, J.A. (1995). School-based prevention programs for children and adolescents. Sage: Thousand Oaks.

Erickson, M.F., Korfmacher, J., \& Egeland, B.R. (1992). Atlachments past and present: Implications for therapeutic intervention with mother-infant dyads. Development and Psychopathology, 4, 4, 495-507.

Fischer, M., Barkley, R.A., Fletcher, K.E., \& Smallish, L. (1993). The adolescent outcome of hyperactive children: predictors of psychiatric, academic, social and emotional adjustment. Journal of the American Academy of Child \& Adolescen Psychiatry, 32, 2, 324-332.

Gleser, J., \& Mendelberg, H. (1990). Exercise and sport in mental health: A review of the literature. Israet Journal of Psychiatry and Related Sciences, 27, 2, 99-112.

Goldberg, D. (1992). Early diagnosis and secondary prevention. In R. Jenkins, J. Newton \& R. Young (Eds.). The prevention of depression and anxiety. London: HMSO.

Goldstein, M.J. (1994). Psychoeducational and family therapy in relapse prevention. Acta Psychiarrica Scandinavica, 89, 54-57.

Gotlib, I.H., \& Hammen, C.L. (1992). Psychological aspects of depression: toward a cognitive-interpersonal integration. Chichester: Wiley.

Grinten, T. van der. De vorming van de ambulante geestelijke gezondheidszorg. Baarn: Ambo. Academisch Proefschrift Erasmus Universiteit Rotterdam.

Hains, A.A., \& Ellman, S.W. (1994). Stress inoculation training as a preventative intervention for high school youths. Journal of Cognitive Psychotherapy, 8, 3, 219-232.

Have, M.L. ten, Lorsheuyd, J.J.G., Bijl, R.V., \& Osterthun, P. (1995). Jaarboek geestelijke gezondheidszorg 1995/96. Utrecht: Tijdstroom. 
Hermanns, J. (1995). Jeugdproblematiek en opvoedingsondersteuning. Tijdschrifi voor Orthopedagogiek, 34, 410-422.

Hiss, H., Foa, E.B., \& Kozak, M.J. (1994). Relapse prevention program for treatment of obsessive-compulsive disorder. Journal of Consulting and Clinical Psychology, 62, 4, 801-808.

Hodgson, R., \& Abassi, T. (1995). Effective mental health promotion: literature review. Cardiff: Health Promotion Wales.

Hodiamont, P.P.G. (1986). Het zoeken van zieke zielen. Academisch Proefschrift. Nijmegen: Sociale geneeskunde reeks 16.

Hoefnagels, C. (1994). Over praten gesproken: effect-evaluatie van de landelijke campagne tegen kindermishandeling 'Over sommige geheiemen moet je praten'. Amsterdam: VU Uitgeverij.

Holman, E.M.P. (1992). De rol van de ziektekostenverzekeraar in de financiering van GGZ-preventie. In M.M.J. Senhorst (Red.), Rendement en financiering GGZ-preventie. Utrecht: Landelijk Centrum GVO/Sectie LOP-ggz.

Hosman, C.M.H. (1996). Investeren in Openbare Geestelijke Gezondheidszorg Preventie: handel in effecten. Tijdschrift Gezondheidsbevordering, 17, 15-31. Hosman, C.M.H., \& Veltman, J.E. (in druk). Programmaontwikkeling en effectmanagement. Nijmegen: Vakgroep Klinische Psychologie en Persoonlijkheidsleer, KUN.

Horwath, E., Johnson, J., Klerman, G.L., and Weisman, M.M. (1992). What are the public health implications of subclinical depressive symptoms? Psychiatric Quaterly, 65, 4, 323 - 337.

Jahoda, M. (1958). Current concepts of positive mental health. New York: Basic Books.

Kellam, S.G., Mayer, L.S., Rebok, G.W., \& Hawkins, W.E. (in press). Effects of improving achievement on aggressive behavior and of improving aggressive behavior on achievement through two preventive interventions: an investigation of causal paths. In B. Dohrenwend (Ed.). Adversity, stress and psychopathology. American Psychiatric Press.

Kellam, S.G., Rebok, G.W., Ialongo, N., \& Mayer, L.S. (1994). The course and malleability of agressive behavior from carly first grade into middle school: results of a developmental epidemiologically-based preventive trial. Journal of Child Psychology and Psychiarry, 35, 2, 259-281.

Keller, M.B. (1988). Diagnostic issues and clinical course of unipolar illness. In A.J. Frances \& R.E. Hales (Eds.), Review of psychiatry. Washington D.C.: American Psychiatric Press.

Kok, I., Konijn, C. \& Geelen, K. (1994). KOPP-zorgen. Evaluatie van preventieve interventies bij kinderen van ouders met psychiatrische problemen. Utrecht: NcGv.

Kühner, C., Angermeyer, M.C. \& Veiel, H.O. (1994). Zur Wirksamkeit eines 
kognitiv-verhaltenstherapeutischen Gruppenprogramma bei der Ruckfallprophylaxe depresiver Erkrankungen. Verhaltenstherapie, 4, 4-12.

Lammeren, P. \& Geelen, K. (1995). Verbitteren of verbeteren. Evaluatie van een programma ter voorkoming van eenzaamheid en depressie bij oudere wedwwen. Utrecht: NcGv.

Lewinsohn, P.M., Hoberman, H.M. \& Rosenbaum, M. (1988). A prospective study of risk factors for unipolar depression. Journal of Abnormal Psychology, 97, 251-264.

Luntz, B.K. \& Widom, C.S. (1994). Antisocial personality disorder in abused and neglected children grown up. American Journal of Psychiarny, 151, 670674.

Markman, H.J., Renick, M.J., Floyd, F.J. Stanley, S.M., Clements, M. (1993). Preventing marital distress through communication and conflict management training: a 4- and 5 year follow-up. Journal of Consulting and Clinical Psychology, 61, 1, 70-77.

Millon, T. (1981). Disorders of personality. DSM-III, Axis II. New York: Wiley.

Molleman, G.R.M., van Driel, W., \& Keijsers, J. (1995). Preventie effectiviteitsinstrument PREFI 1.0. Utrecht: Landelijk Centrum GVO.

Molleman, G.R.M., \& van Nies, H.A.M. (1995). Trendonderzoek NVPG 1994. Nijmegen/Leiden: Nederlandse Vereniging voor Preventie en GVO.

Mrazek, P.J., \& Haggerty, R. (Ed.) (1994). Reducing risks of mental disorder: Frontiers for preventive intervention research. Washington: National Academy Press.

Munoz, R.F. (1993). The prevention of depression: Current research and practice. Applied and Preventive Psychology, 2, 21-33.

Muñoz, R., \& Ying. Y.W. (1993). The prevention of depression: research and practice. Baltimore: The Johns Hopkins University Press.

National Institute of Mental Health (1995). A plan for prevention research for the National Institute of Mental Health. Rockville, Maryland.

National Mental Health Association (1995). Getting started: The NMHA directory of model programs to prevent mental disorders and promote mental health. Alexandria, VA: NMHA.

Nota 2000, over de ontwikkeling van gezondheidsbeleid: feiten, beschouwingen en beleidsvoornemens. Tweede kamer, vergaderjaar 1985-1986, 19 500, nrs. 1-2.

Olds, D.L. (1988). The Prenatal/Early Infancy Project. In R.H. Price, E. L. Cowen, R.P. Lorian \& J. Ramos-McKay (Eds.), 14 ounces of prevention: a casebook for practioners. Washington: American Psychological Association.

Olweus D. (1992). Bullying among schoolchildren: Intervention and prevention. In: R. DeV. Peters, R.J. McMahon \& V.L. Quinsey (Eds), Agression and 
Violence throughout the Life Span. Newbury Park, California: Sage.

Ormel, J. (1987). Primaire preventie van veel voorkomende psychische stoornissen: hoe mogelijk is het onmogelijke? Maandblad Geestelijke Volksgezondheid, 42, 1358-1369.

Poppel, J. van, Maas, J., Kamphuis, P., \& Kroesbergen, I. (1995). In R. Sanderman, W.J.A. van den Heuvel \& B. Krol (Red.). Interveniëren in determinamten van gezondheid: resullaten van een onderzoeksprogramma. Assen: Van Gorcum.

Price R.H., Ryn M. van \& Vinokur A.D. (1992). Impact of a preventive job search intervention on the likelihood of depression among the unemployed. Journal of Health and Social Behavior, 33, p. 158-167.

Raad voor Gezondheidsonderzoek (1996). Prioriteiten in preventieonderzoek. 'sGravenhage.

Reid, J.H. (1993). Prevention of conduct disorder before and after school entry: relating interventions to developmental findings. Development and Psychopathology, 5, 243-262.

Reimann, H. (1967). Die Mental Health Bewegung. Tübingen: Mohr.

Schnabel, P. (1995). De weerbarstige geestesziekte: naar een nieuwe sociologie van de geestelijke gezondheidszorg. Nijmegen: SUN.

Rutz, W., Carlsson, P., von Knorring, L., \& Walinder, J. (1992). Cost-benefit analysis of an educational program for general practitioners by the Swedish Committee for the Prevention and Treatment of Depression. Acta Psychiatr. Scand., 85, 457-464.

Scenariocommissie Geestelijke Volksgezondheid en Geestelijke Gezondheidszorg (1990). Zorgen voor geestelijke gezondheid in de toekomst. Utrecht: Bohn, Scheltema \& Holkema.

Schnabel, P. (1988). De toekoomst heeft tijd nodig. In C.A.L. Hoogduin, B.P.R. Gersons, H.G.M. Rooymans e.a. (Red.). Jaarboek voor psychiatrie en psychotherapie 1987-1988. Deventer: Van Loghum Slaterus.

Schnabel, P. (1995). De weerbarstige geestesziekte: Naar een nieuwe sociologie van de geestelijke gezondheidszorg. Nijmegen: SUN.

Schnabel, P., Bijl, R. \& Hutschemaekers, G. (1992). Geestelijke volksgezondheid in de jaren '90. Utrecht: Nederlands centrum Geestelijke volksgezondheid.

Schweinhart, L.J., \& Weikart, D.B. (1988). The High/Scope Perry Preschool Program. In R.H. Price, E. L. Cowen, R.P. Lorian \& J. Ramos-McKay (Eds.), 14 ounces of prevenion: a casebook for practioners. Washington: American Psychological Association.

Spaans, M. \& Geelen (1995). Weer zin in werk. Evaluatie van vier Riaggtrainingen ter voorkoming van psychische overbelasting op het werk. Utrecht: NcGv. 
Tableman, B., Feis, C.L., Marciniak, D., \& Howard, D. (1985). Stress management training for low-income women. Prevention in Human Services, 4, $71-85$.

Timmerman, I., \& Emmelkamp, P.M.G. (1995). De preventieve effecten van een stresshanteringscursus. In R. Sanderman, W.J.A. van den Heuvel \& B. Krol (Red.). Interveniëren in determinanten van gezondheid: resultaten van een onderzoeksprogramma. Assen: Van Gorcum.

Tudor, K. (1996). Mental health promotion: paradigms and practice. London: Routledge.

Veltman, J.E., Ruiter, M., \& Hosman, C.M.H. (1996). Stemming maken: versterken van weerbaarheid en verminderen van depressieve klachten bij jongeren. Nijmegen: Vakgroep Klinische Psychologie en Persoonlijkheidsleer, KUN. Onderzoeksrapport Research Groep Preventie en Psychopathologie.

Vinokur, A., van Ryn, M., Gramlich, E.M., \& Price, R.H. (1991). Long-term follow-up and benefit-cost analysis of the JOBS program: a preventive intervention for the unemployed. Journal of Applied Psychology, 76, 1-7.

Vries, W.J. de, Hosman, C.M.H., \& Engels, M.C.L.J. (1995). Visies op effectbepalende condities in de preventieve geestelijke gezondheidszorg. Nijmegen: Vakgroep Klinische Psychologie en Persoonlijkheidsleer, KU Nijmegen. Onderzoeksrapport Research Groep Preventie en Psychopathologie.

Widenfelt, B. van, Hosman, C., Schaap, C., \& Staak, C. van der (1996). The prevention of relationship distress for couples at risk: a controlled evaluation with nine-month and two-year follow-ups. Family Relations, 45, 156-165.

Wilson, P.H. (1992). Depression. In P.H. Wilson (Ed.), Principles and practice of relapse prevention. New York: Guilford Press.

World Health Organization (1985). Targets for health for all. WHO Regional Office for Europe, Copenhagen.

Zigler, E., Taussig, C., \& Black, K. (1992). Early childhood intervention: a promising preventative for juvenile delinquency. American Psychologist, 47, 997-1006. 
Noten

1. C.W. Beers (1908), A mind that found itself (p. 218): "........ to prevent a complete and incurable mental breakdown".

2. Het begrip psychohygiëne is al ruim 150 jaar oud, en de term 'preventie van geestesziekte' wordt al meer dan 100 jaar gebruikt (Reiman, 1967).

3. In H. Reimann (1967).

4. De Nota 2000 , in 1986 uitgebracht door het toenmalige Ministerie van Welzijn, Volksgezondheid en Cultuur, beschrijft de contouren voor een lange termijnbeleid van de overheid op het terrein van de volksgezondheid. De Nota gaat voor een belangrijk deel over het bevorderen van gezondheid en de preventie van ziekten. Zij vormt de Nederlandse bewerking van de 'Health for All by the year 2000' strategie van de Wereld Gezondheids Organisatie (WHO, 1984).

5. In die tijd riep de term 'hygiene' te veel associaties op met de propaganda voor de gezondheids- en rassenideologie van het Derde Rijk.

6. Het laatste World Congress van de Federatie in 1995 in Dublin omvatte niet minder dan 130 presentaties in de sector preventie en geestelijke gezondheidsbevordering.

7. Prof. Bouwman, hoogleraar psychiatrie en neurologie, was een van de grondleggers van de Nederlandse Geestelijke Volksgezondheidsbeweging. Reeds in de jaren twintig pleitte hij ervoor dat instellingen op het terrein van gezondheidszorg, maatschappelijke zorg en krankzinnigenzorg, en beroepbeoefenaren als psychiaters, psychologen en maatschappelijk werkers zowel een taak hebben met betrekking tot lotsverbetering en behandeling van geesteszieken, als ten aanzien van het voorkómen van geestesziekten.

8. Veel van deze activiteiten zijn inmiddels zozeer doel en onderdeel van de curatieve zorg geworden dat ze veelal niet meer als preventie benoemd en herkend worden. Ze worden vaak beschouwd als integrale onderdelen van goede curatieve zorg aan psychiatrische patiënten of als innovaties van deze curatieve zorg.

9. Al voor de tweede wereldoorlog en direct erna werden ambulante voorzieningen op het terrein van de geestelijke gezondheidszorg ook wel aangeduid met de term 'geestelijke volksgezondheid'. Voorbeelden: Hervormde Stichting voor Geestelijke Volksgezondheid voor Amsterdam en omgeving, Districtsbureaus voor Geestelijke Volksgezondheid (Van der Grinten, 1987). 
10. Met name door de Katholieke Centrale Vereniging voor Geestelijke Volksgezondheid zijn in de vijftiger en zestiger jaren een grote reeks voorlichtingspublikaties voor sleutelfiguren verspreid.

11. Deze sterk moralistische inslag was een van de redenen waarom de beweging in de zestiger jaren in een malaise raakte.

12. Deze oriëntatie paste bij de identiteit van de eerste financier van ggzpreventie, het toenmalige Ministerie van Cultuur, Recreatie en Maatschappelijk Werk CRM).

13. Deze schatting is gebaseerd op gegevens uit het Trendonderzoek 1994 van de Nederlandse Vereniging voor Preventie en GVO (Molleman \& van Nies, 1995).

14. Zie het eindrapprt van de Scenariocommissie Geestelijke Volksgezondheid en Geestelijke Gezondheidszorg (1990).

15. Zie onder meer Scenariocommissie GV en GGZ (1990) en Schnabel, Bijl \& Hutschemaekers (1992).

16. Gebaseerd op gegevens ontleend aan Ten Have, Lorsheyd, Bijl \& Osterthun (1995).

17. Het grootste deel van mensen met dergelijke problemen komt niet bij geestelijke gezondheidszorg tcrecht maar bij de huisarts, en een deel ontvangt helemaal geen hulp (Mrazek \& Haggerty, 1994). Voor depressie is dat vermoedelijk zo'n 30 tot 50\% (Goldberg, 1992; Munoz \& Ying, 1993). Zelfs bij zeer ernstige psychiatrische stoornissen, zoals psychosen blijft een deel onbelandeld (Hodiamont, 1986).

18. Ten Have, Lorsheyd, Bijl \& Osterthun (1995).

19. Mrazek \& Haggerty (1994, p. 87).

20. Geciteerd in Beers (1908; editie 1950, p. 248).

21. Hierin geven de belangrijkste Amerikaanse preventiedeskundigen een overzicht van wat er op dit moment bekend is aan risicofactoren en aan programma's om een aantal van deze risicofactoren met succes te beïnvloeden.

22. Cuijpers (1993); Kok, Konijn, Geelen (1994); Hoefnagels (1994); Van Lammeren \& Geelen (1995); Spaans \& Geelen (1995); Timmerman \& Emmelkamp (1995); Bijstra van der Kooi \& Oostra (1995); Daamen \& van Mierlo (1995); van Poppel, Maas, Kamphuis \& Kroesbergen (1995); Veltman, Ruiter \& Hosman (1996); Widenfelt, Hosman, Schaap \& van der Staak (1996). 
23. De hiergenoemde variabelen worden door vele auteurs beschouwd als belangrijke kenmerken van geestelijke gezondheid (o.a. Jahoda, 1958; Tudor, 1996).

24. Sommige auteurs gebruiken hier de term 'generieke factoren'.

25. Ook Hermanns heeft in een recent overzichtsartikel over jeugdproblematiek en opvoedingsondersteuning beargumenteerd dat preventieve interventies met name gericht zouden moeten worden op het versterken van protectieve factoren in situaties waarin zich een cumulatie van risicofactoren voordoet (Hermanns, 1995).

26. Getting Started: The NMHA Directory of Model Programs to Prevent Mental Disorders and Promote Mental Health, gepubliceerd door de National Mental Health Association (1995).

27. Een voorbeeld hiervan is de 'Coping with Depression Course' van Lewinsolin, welke thans in een gezamelijk onderzoek over zes Europese landen op haar effect wordt geëvalueerd.

28. Zie o.a. Tableman, Feis, Marciniak \& Howard (1985), Cuijpers (1995a, 1995b), Muñoz \& Ying (1993), Muñoz (1993), Hains \& Ellman (1994), Gleser \& Mendelberg(1990), Erickson, Korfmacher \& Egeland (1992).

29. Eerder hebben Price, van Ryn \& Vinokur (1992) al cen vermindering aangetoond van het aantal depressieve episoden bij werkelozen met een vehoogd risico als gevolg van deelname aan training in het zoeken van werk. De training betrof 8 sessies verdeeld over twee weken. Gemeten over een periode van 2,5 jaar bleek $39 \%$ van de controlegroep een periode van klinische depressie te hebben meegemaakt, terwijl dit in de experimentele conditie (trainingsprogramma) 'slechts' bij $25 \%$ van de deelnemers het geval was. Aan de validiteit van de door hen gehanteerde methode voor het vaststellen van een klinische depressie kan echter getwijfeld worden.

30. Zie onder meer Gotlib \& Hammen (1992), Cicchetti \& Toth (1992), Hosman, Veltman \& Ruiter (1993) en Mrazek \& Haggerty (1994).

31. Zo vond Brown (1992) dat bij gehuwde moeders uit lagere inkomensgroepen een risico van $10.6 \%$ op een nieuwe depressieve stoornis binnen een jaar. Dit risico steeg tot $20.6 \%$ wanneer de moeders in dat jaar een ernstige stresserende gebeurtenis meemaakten, en zelfs tot $37 \%$ wanneer ze daarbij niet de sociale steun van hun partner kregen die ze verwacht hadden te zullen krijgen.

32. Voor een meer volledig overzicht van de huidige stand van zaken met betrekking tot effectiviteit wordt verwezen naar de recente publikatie 'Investeren in OGGZ-preventie: handel in effekten' (Hosman, 1996), naar het rap- 
port 'Reducing risk of mental disorders' (Mrazek \& Haggerty, 1994) en de publikatie 'Effective mental health promotion: literature review' (Hodgson \& Abassi, 1995).

33. Zigler, Taussig \& Black (1992), Reid (1993), Fischer, Barkley, Fletcher \& Smallish (1993) en Kellam, Rebok, Ialongo \& Mayer (1994).

34. Durlak (1995), Mrazek \& Haggerty (1994), Zigler et al. (1992) en Kellam, Mayer, Rebok \& Hawkins (in press).

35. Het relatieve risico op het onstaan van depressie in engere zin bleek bij mensen met een paniek-stoornis 3.4 te bedragen.

36. Zie onder meer het PREFFI-instrument ontwikkeld door het Nederlands Instituut voor Gezondheidsbevordering en Ziektepreventie (Molleman, van Driel \& Keijsers, 1995) en de publikatie 'Programma-ontwikkeling en effectmanagement' (Hosman \& Veltman, in druk).

37. De onlangs opgerichte Europese Clifford Beers Foundation werkt thans in samenwerking met de European WHO Task Force for Mental Health Promotion and Prevention, de European Regional Council van de World Federation of Mental Health aan de voorbereiding van een dergelijk Europees informatienetwerk.

38. Zie Coie, Watt, West et al. (1993).

39. Plan for Prevention Research for the National Institute of Mental Health. A report to the National Advisory Mental Health Council (NIMH, 1995).

40. Raad voor het Gezondheidsonderzoek (1996). Prioriteiten in preventieonderzoek.

41. Dat geldt zowel voor hun wisselwerking gedurende de fasen van de levensloop als gedurende de fasen in de ontwikkeling van een specifiek probleem.

42. Een eerste aanzet tot het inventariseren van deze praktijkkennis onder preventiewerkers en gvo-functionarissen is onlangs gegeven in het kader van de Ontwikkelingsprojecten ggz-preventie (Bosma, Hosman, de Vries \& Veltman, 1994; de Vries, Hosman \& Engels, 1995). Naast een reeks diepteinterviews over programmaontwikkeling is hierbij een enquête-onderzoek uitgevoerd onder 212 praktijkwerkers waarin naar hun visie is gevraagd over de factoren die bepalend zijn voor de effectiviteit van preventieve interventies.

43. Bij preventie gaat het er immers niet zozeer om te voorkómen dat mensen met problemen geconfronteerd worden maar vooral om ervoor te zorgen dat mensen zelf of met behulp van hun sociale omgeving in staat zijn goed met problemen of dreigende problemen om te gaan. 
44. Binnen de RIAGG's is de capaciteil voor preventie in de periode '92-'94 zelfs met $1.7 \%$ teruggelopen (Bron: NVAGG). Wel is er recentelijk enige aanvullende investeringsruimte vrijgekomen op basis van stimuleringsgelden voor Openbare Geestelijke Gezondheidszorg.

45. COTG-norm (bron: Doelmatig behandelen, Rapport van de interdepartementale werkgroep 'Financieringssysteem van forensisch psychiatrische hulpverlening. Ministerie van Justitie).

46. Daar gaat een gemiddeld verblijf van ongeveer 2 jaar in een gevangenis en huis van bewaring aan vooraf. Voegen we daar nog aan toe de kosten voor het justitiële apparaat vanaf de eerste proces tot aan de definitieve beëindiging van de TBS, bijvoorbeeld in verband met verlengingen, proefverloven, ontvluchtingen, beeindiging van de TBS, dan kost dat de overheid $z 0^{\prime} n 2$ miljoen gulden per TBS-patiënt. Daarkomt nog bij de financiële en psychische schade die slachtoffers en hun naasten Jopen. Bovendien gaat aan een dergelijk misdrijf vaak een lange geschiedenis vooraf van contacten met hulpverleners, opnames in tehuizen, eerdere processen en verblijf in gevangenissen. Het geheel kan geschat worden op tenminste 3 miljoen. Vermoedelijk liggen de kosten veel hoger omdat in dit bedrag geen rekening is gehouden met de eventuele werkeloosheids- en bijstandsuitkeringen die zijn betaald in de carrière voorafgaande aan de TBS-periode en in de periode daarop volgend. Evenmin zijn in dit bedrag nog meegerekend de kosten in verband met nazorg en eventuele recidive.

47. Het aantal TBS-opleggingen vertoont de laatste jaren een sterk stijgende lijn. Schommelde het aantal in de tachtiger jaren nog rond de 94, in 1992 bedroeg het aantal 112 en in 1993134 (Ten have e.a., 1996). Wanneer deze stijging zich doorzet zal het antal over 1996 vermoedelijk liggen tussen 180 en 200 .

48. De personeelskosten, inclusief werkgeverslasten, van preventiefunctionarissen en gezondheidsvoorlichters bij RIAGG's en GGD-en bedroeg in 1994 totaal 28,5 miljoen gulden (Molleman \& van Nies, 1995). Het aantal nieuwe uitkeringen voor arbeidsongeschiktheid vanwege psychische stoornissen betrof in 199424.396 personen. Een reductie van 100 personen houdt een risicovermindering in van $0.4 \%$. Een wao-uitkering bedraagt gemiddeld $f$ 81.827,- per jaar, en opgeteld over een periode van 5 jaar $f$ 404.135,-. Een geslaagde preventie bij 100 personen levert een besparing op van ruim 40 miljoen gulden. Dit is gelijk aan $140 \%$ van de totale personeelslasten voor preventie en gezondheidsvoorlichting bij RIAGG's en GGD-en tezamen.

49. Zie onder meer Rutz, Carlsson, Von Knorring \& Walinder (1992), Schweinhart \& Weikart (1988), Berrueta-Clement et al. (1984), Vinokur, van Ryn, Gramlich and Price (1991) en Bloom \& Hodges (1988). 
50. Deze conclusie is gebaseerd op een landelijke screening die door de afdeling Landelijk Ondersteuning Preventie-ggz (LOP-ggz) van het Trimbos Instituut is uitgevoerd onder de RIAGG-preventiewerkers.

51. Projecten voor Psychiatrisch Intensieve Thuiszorg (PIT-projecten).

52. Deze uitspraak houdt geen pleidooi in voor het terugtrekken van preventiewerkers uit hulpverleningsteams, maar wel een pleidooi voor het behoud van een eigenstandige preventie-eenheid waarin preventiedeskundigen in nauwe onderlinge samenwerking de gelegenheid krijgen op een systematische wijze te werken aan de ontwikkeling van nieuwe programma's, aan de innovatie van het beleidsdenken op het terrein van de ggz-preventie en aan de verdere ontwikkeling van hun vakgebied. Zoals dat evenzeer geldt voor het terrein van de psychotherapie, is de verdere ontwikkeling van het vakgebied van de ggz-preventie niet alleen een taak van universiteiten en onderzoeksinstituten, maar evenzeer een taak van praktijkinstellingen. Een dergelijke preventieeenheid zou gecombineerd kunnen worden met het lidmaatschap van hulpverleningsteams. 